OECD Taxation Working Papers No. 4

\title{
Trends in Top Incomes and their Tax Policy Implications
} Stephen Matthews 


\section{OECD CENTRE FOR TAX POLICY AND ADMINISTRATION}

\section{OECD TAXATION WORKING PAPERS SERIES}

This series is designed to make available to a wider readership selected studies drawing on the work of the OECD Centre for Tax Policy and Administration. Authorship is usually collective, but principal writers are named. The papers are generally available only in their original language (English or French) with a short summary available in the other.

The opinions expressed and arguments employed in these papers are the sole responsibility of the author(s) and do not necessarily reflect those of the OECD or of the governments of its member countries.

Comments on the series are welcome, and should be sent to either ctp.contact@oecd.org or the Centre for Tax Policy and Administration, 2, rue André Pascal, 75775 PARIS CEDEX 16, France.

Applications for permission to reproduce or translate all, or part of, this material should be sent to OECD Publishing, rights@oecd.org or by fax 33145249930.

Copyright OECD 2011 


\section{ACKNOWLEDGEMENT}

This paper makes extensive use of data from The World Top Incomes Database prepared by Fecundo Alvaredo, Tony Atkinson, Thomas Piketty, Emmanuel Saez and various collaborators (and available at http://g-mond.parisschoolofeconomics.eu/topincomes/), supplemented in some cases by data from member countries. The charts were prepared by Michael Sharratt and the text builds on papers prepared by Professor Christopher Heady on top income shares and tax policy for the Working Party No.2 on Tax Policy and Tax Statistics of the Committee on Fiscal Affairs. These papers were discussed by the Working Party and the present paper has benefitted from the comments of country Delegates. 


\section{EXECUTIVE SUMMARY}

This paper uses data derived from tax returns to analyse trends in the share of pre-tax personal income going to top income recipients. These data provide a more reliable source of information on top incomes than household surveys and allow a perspective of almost a century. Since the early 1980s there has been a recovery in the share of top incomes, especially in the share of the top percentile group. The increase started earlier and has been greater in the US than elsewhere. Strong upward trends can also be seen in other English-speaking countries, but such trends are more muted in Continental European countries. The differences in trends between countries may reflect measurement issues to some degree.

An important feature of the increased share is that it is mostly attributable to higher employment and business income, not capital income, and reflects such factors as the incentive effects of cuts in (top) marginal tax rates and the fact that the remuneration of top executives and finance professionals has become increasingly related to 'performance', particularly through the use of stock and stock options.

The policy implications of these trends depend in part on income mobility; and the limited data available suggest that there is significant mobility and that its scale has decreased only slightly over time. They also depend on the likely behavioural response to increased taxation of top incomes, where the empirical literature suggests that taxable income elasticities in some countries can be large. The paper considers the pros and cons of possible reforms in the light of such evidence. 


\title{
TRENDS IN TOP INCOMES AND THEIR TAX POLICY IMPLICATIONS
}

\author{
Stephen Matthews ${ }^{1}$
}

\section{Introduction}

1. This paper looks at developments in top incomes, particularly the top percentile group of the income distribution. There are a number of reasons for doing so:

a) The data indicate that there have been large changes in the share of top incomes in total incomes in recent decades in many countries; and that these trends can have a significant impact on overall measures of income distribution. For instance Atkinson, Piketty and Saez (2009) note that the 14 percentage point increase in the share of the top percentile group in the US between 1976 and 2006 would produce a rise of 8.4 per cent in the overall Gini coefficient for pre-tax incomes.

b) Data based on income information on tax returns can provide a much fuller and more accurate picture of the top of the income distribution than the data from household surveys that is normally used to analyse trends in inequality.

c) The main drivers of trends in top incomes may differ from those determining trends for the rest of the income distribution.

d) The availability of long series for data based on tax returns permits a correspondingly longterm perspective on trends in income distribution (or at any rate on the shares of top income recipients).

2. After the discussion of the data sources in Section 2 (which is supplemented with more detail in annex 1), the rest of the chapter is structured as follows:

- Section 3 sets out statistics for the trends in top incomes, focusing on the last 30 years.

- Section 4 discusses explanations of these trends.

- Section 5 considers the potential implications for tax policy.

Chief Tax Economist, Centre for Tax Policy and Administration, OECD. Email: Stephen.Matthews@oecd.org. 


\section{Data on top incomes}

3. Statistics based on data from personal income tax returns have been collected in a number of countries for many years. Typically, they show the numbers of taxpayers in a number of given income ranges and their total income. Over the past ten years or so there has been an intensive programme of work led by Atkinson, Piketty, Saez and various associates to relate these figures to information on the incomes of the population as a whole in order to derive estimates of the share of top income recipients in total income. This work involved a number of steps, Atkinson and Piketty (2007):

a. Control total for population. The number of taxpayers filing tax returns has to be related to the size of the total (adult) population in order to calculate income shares in relation to the total (not just the taxpaying) population. Allowance also has to be made for the fact that in some countries couples are often required to file joint tax returns rather than being separately assessed on an individual basis.

b. Control total for income. The incomes of those filing tax returns (often a small minority in the early days of income tax) need to be related to total household income. This can require a substantial amount of imputation of the incomes of non-taxpayers (and taxpayers whose tax liabilities are deducted at source and do not have to file tax returns) using, for instance, estimates based on national accounts aggregate figures. In more recent years the rise in the proportion of individuals that have to file tax returns makes this less of a problem.

c. Interpolation. As the original statistics are often for the numbers of income taxpayers in each income range, some method of interpolation is needed in order to be able to calculate the shares of, say, the top $1.0 \%$ or $0.1 \%$. The standard statistical approach here is to assume a Pareto distribution. A range of values for the exponent of the formula may fit the facts, though in most cases interpolation methods seem unlikely to be a major source of error, Atkinson and Piketty (2007).

4. Atkinson, Piketty, Saez and their collaborators have applied such statistical procedures to the income tax data for some 22 countries to derive estimates of the distribution of income over runs of years of up to a century or more. These include 17 OECD countries (Australia, Canada, Finland, France, Germany, Ireland, Italy, Japan, Netherlands, New Zealand, Norway, Portugal, Spain, Sweden, Switzerland, United Kingdom and United States.) The present paper is based on their work, with additional information (particularly for later years) supplied by OECD member countries themselves.

5. Income data derived from tax returns have a number of strengths, but also have limitations. The latter are described in more detail in Annex 1. They can have significant implications not only for crosscountry comparisons at any given point in time, but also for the interpretation of trends over time. Nevertheless the advantages of tax return data are substantial:

a. Tax data should cover all high income recipients. It can provide 'census' rather than sample data; and, where samples have been used, they are often large, with a comprehensive sample frame (with over-sampling of high income recipients) that should not suffer from the high non-response rates of survey data at higher levels of income. (High income recipients tend to be less willing than average to respond to household income and expenditure surveys). This is especially important given the wide range of income levels in the top income groups (e.g. the average income of the top $0.01 \%$ may be many times the average income of the top $1 \%$.)

b. The tax authorities audit the income information provided by taxpayers and impose penalties for under-declaration of income. There are thus incentives for taxpayers to supply correct information. 
c. Data are often available for long runs of years. This is an important consideration given that the income distribution tends to show secular trends.

d. Information may be available on the breakdown of incomes between earnings, business income and capital income; and on the industrial sector in which the bulk of income is earned.

e. Similar methodologies can be applied to income tax data for different countries to derive broadly comparable data series.

\section{Comparability of data on top incomes}

6. Considerable care is needed in comparing top income shares between countries and over time in a single country. Measurement issues include cross-country differences (and changes over time) in

- the concept of income that is measured,

- the availability of data for income measures including capital gains,

- the extent of tax planning and tax evasion, and

- the definition of the tax unit.

7. It seems likely that the variations in these factors will be greater between countries than within a country over time, especially if the time period is fairly short and includes few significant changes in the tax law. For this reason, the emphasis in this paper is on the evolution of top income shares within countries rather than comparisons across countries, although there will also be comparisons in the changes in top tax shares between countries.

8. This is a substantial list of limitations. In many cases, though, the direction of any bias in evident and, with further work on tax-return income data, its extent can probably be estimated too. Economists and other analysts have used household survey data for many years and thereby built up a reasonably full picture of their strengths and weaknesses. Use of tax return data is more recent and, with time and further analysis, the magnitude of biases and how best to adjust for them are likely to become better known. This could inter alia increase their international comparability.

\section{Trends in the share of top incomes}

\section{Introduction}

9. This section presents statistics on trends in the share of top income recipients in total income. It focuses on the top percentile group and the 17 OECD countries for which data based on tax returns are available. It also looks at the top decile group and the top $0.1 \%$ - see Annex 2 for more detailed charts. The characteristics of the top income recipients are then discussed, notably the type of income they receive (salaries, business income, capital income, capital gains) and their occupation. Finally, the section considers the information based on panel data that is available for a handful of countries on the mobility of taxpayers in and out of the top income groups.

\section{Trends}

10. Data for the share of the top percentile group in total income are set out in figures $1-3$. For the reasons discussed above the concepts of income are not strictly comparable, but the chosen measures are as wide as possible (but excluding capital gains). These data come from the data appendix to Atkinson, 
Piketty and Saez $(2009)^{2}$, with additional information from country delegates in some cases. The information all comes from tax records, apart from the data for Finland.

11. Figure 1 shows the shares of the top percentile group in pre-tax income for Australia, Canada, Ireland, New Zealand, the United States and the United Kingdom from 1910 to 2008 (or the latest available year). The data show considerable year to year variability, but also shows a clear downward trend in the share for all six countries, followed by a substantial increase starting in the late1970s or 1980s. In the case of the United States, the share of the top 1\% in 2007 had almost reached the same levels as before the First World War.

12. Figure 2 shows the top percentile group's share for France, Germany, Japan, the Netherlands and Switzerland. These countries also show a marked reduction in the first half of the twentieth century, but do not show the same upward trend from the early 1980s onwards as the English-speaking countries shown in Figure 1. Some increase in the share of the top percentile group is, though, apparent from the mid-1990s onwards.

13. Figure 3 shows the top percentile group's share for Finland, Italy, Norway, Portugal, Spain and Sweden. Again, there are declines in the first half of the twentieth century, followed by an increase, with the size of the increase lying somewhere between the countries in figure 1 and those in figure 2. Spain only has data from 1981 and shows a small increase in the top $1 \%$ share since then. Denmark is not shown but its data started in 1990 and show a similar modest increase.

14. Thus the share of top income recipients in total income in OECD countries was generally very high before the First World War. There was then a large secular decline in their share which was particularly sharp during the World War II period. The drop particularly reflected a decline in capital (rather than labour) incomes. Capital incomes tended to decline in the inter-war period and then fell sharply during the Second World War.

15. Top income shares tended to remain broadly unchanged or to decline further in the 1950s and 1960s, despite the long period of high growth rates in most OECD countries. From the 1980s onward the share of top income recipients has recovered strongly in the US and, to a lesser degree, other Englishspeaking countries. This has been associated more with a rise in the incomes of the 'working rich' (e.g. the remuneration of top executives) rather than a recovery of capital incomes. More recently, Continental European countries have also seen a (generally much more muted) rise in the share of top incomes.

16. Table 1 shows in more detail developments in the share of the top percentile group since 1970 . Most OECD countries have experienced an upward trend in the share of the top $1 \%$ that started in the 1980s after a period of substantial decline. The exceptions are Germany, ${ }^{3}$ the Netherlands and Switzerland, which have only shown evidence of increasing shares of the top $1 \%$ more recently. In addition, there was wide variation in the strength of the upward trends that were observed, with the United States showing particularly large increases.

http://g-mond.parisschoolofeconomics.eu/topincomes

The upturn in top income shares in Germany is not included in the data set but is shown by Bach, Corneo and Steiner (2007), using a slightly different approach. 


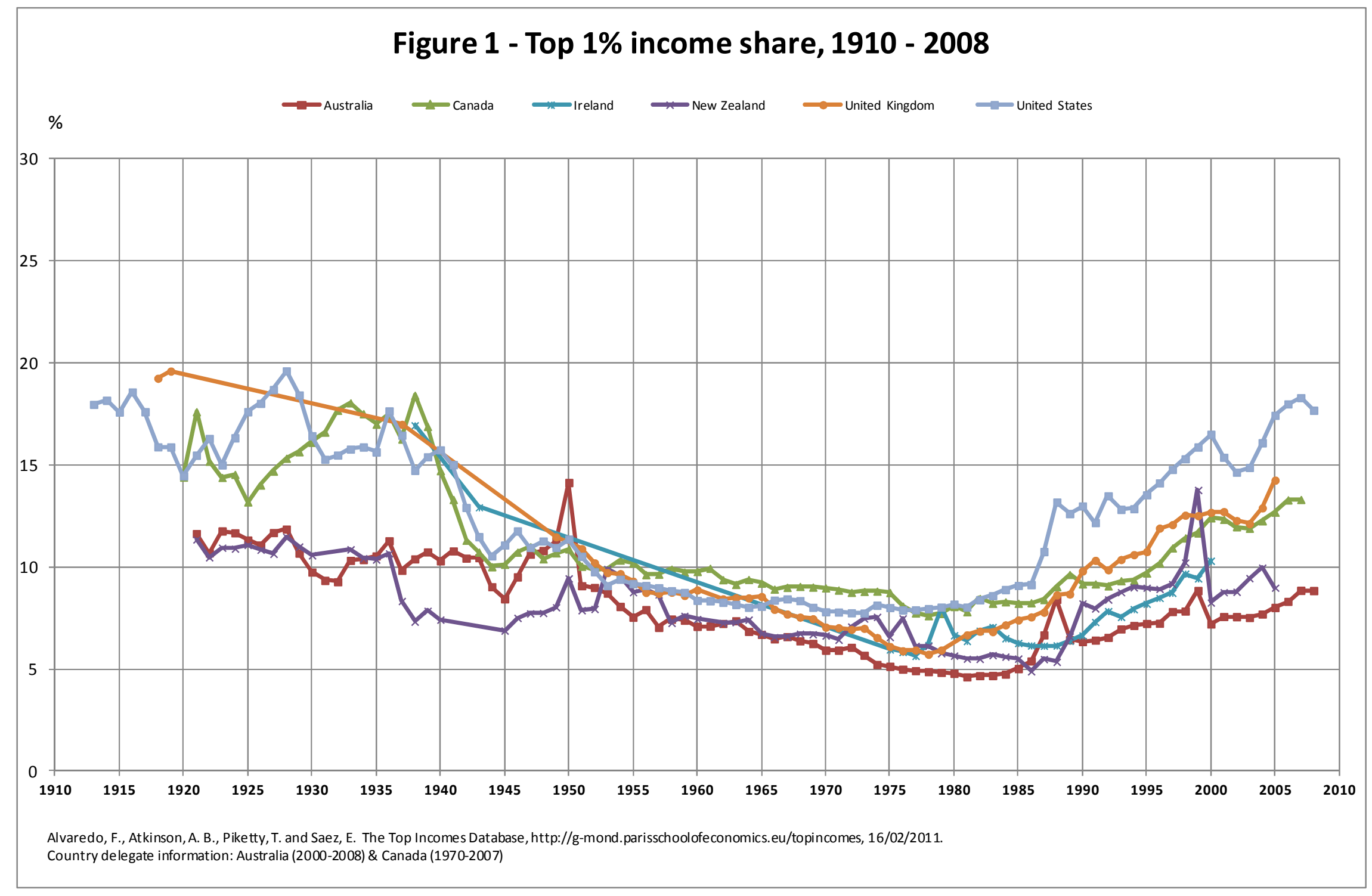




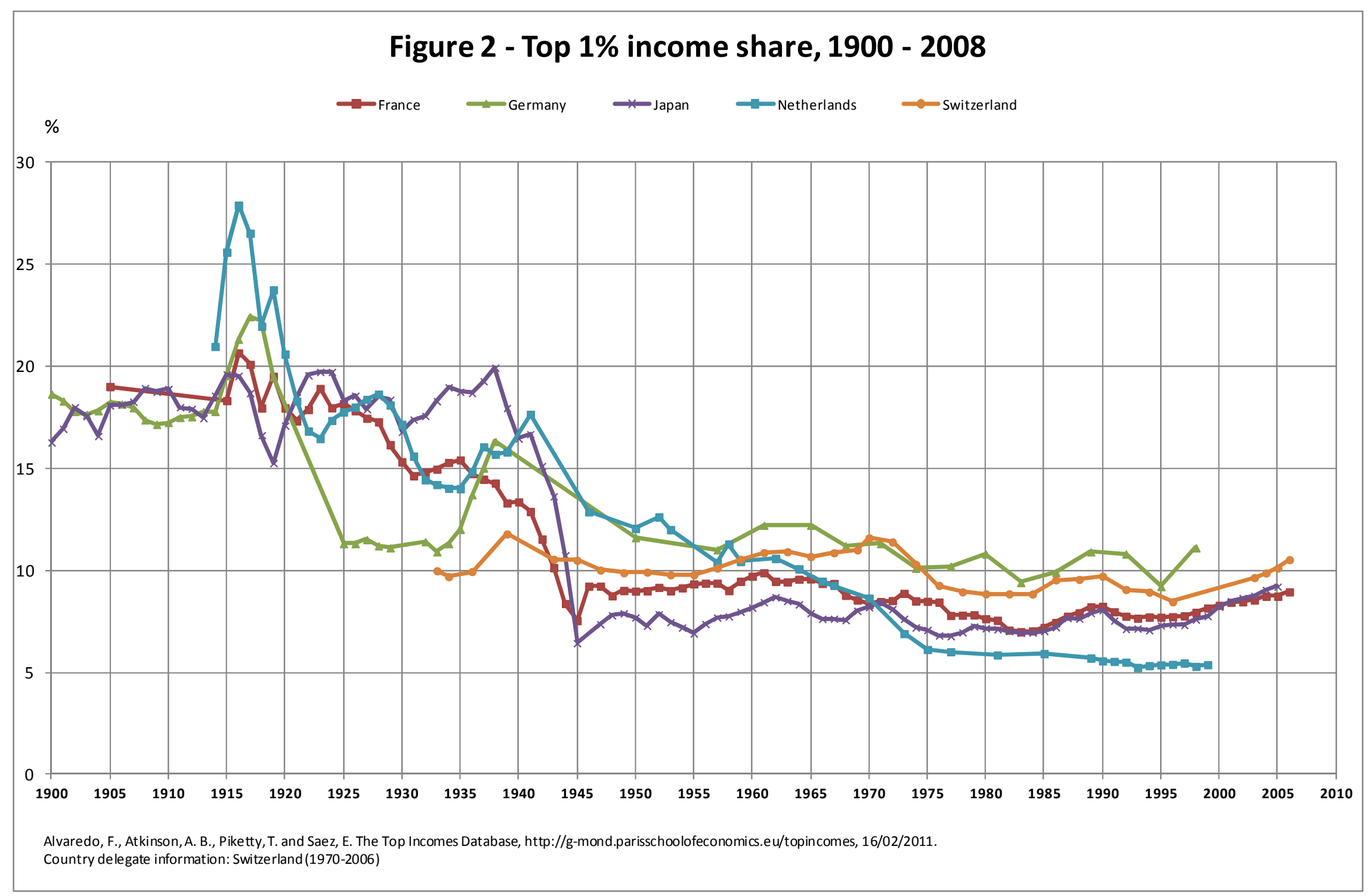




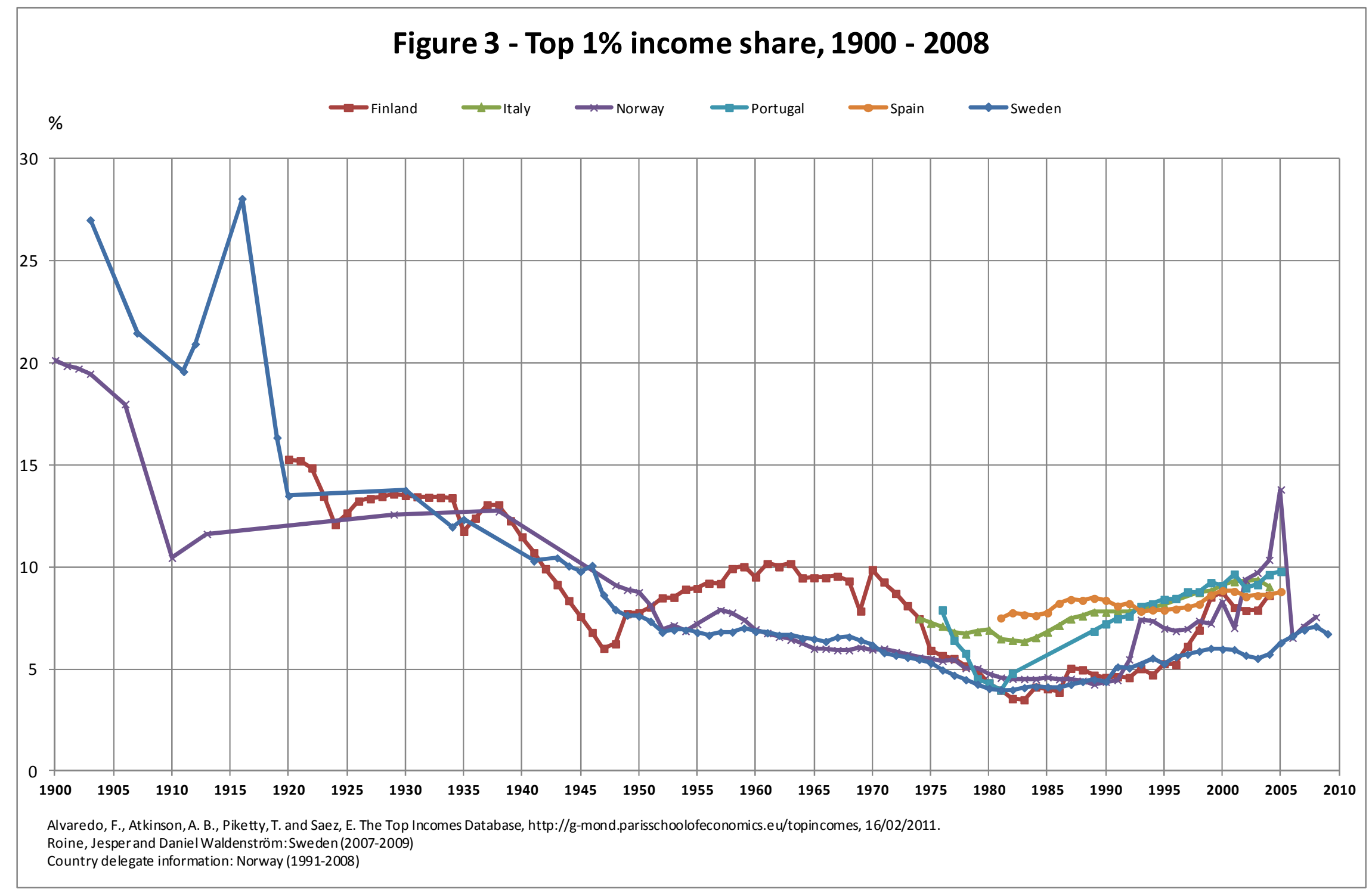


Table 1: Share of top $1 \%$ in selected years

\begin{tabular}{|c|c|c|c|c|c|c|c|c|c|c|c|c|}
\hline Year & 1970 & 1980 & 1990 & 2000 & 2001 & 2002 & 2003 & 2004 & 2005 & 2006 & 2007 & 2008 \\
\hline Australia & 5.9 & 4.8 & 6.3 & 7.2 & 7.6 & 7.6 & 7.5 & 7.7 & 8.0 & 8.3 & 8.9 & 8.8 \\
\hline Belgium & & 7 & 6.3 & 7 & 6.7 & 7.3 & 7.2 & 7.6 & 7.5 & 7.7 & & \\
\hline Canada & 9.0 & 8.1 & 9.2 & 12.4 & 12.3 & 12.0 & 11.9 & 12.3 & 12.7 & 13.3 & 13.3 & \\
\hline Denmark & & 5.2 & 5.1 & 6.6 & 6.3 & 5.8 & 6.3 & 6.6 & 6.3 & 7.1 & 7.4 & 6.5 \\
\hline Finland & 9.9 & 4.3 & 4.6 & 8.8 & 8.0 & 7.9 & 7.9 & 8.6 & & & & \\
\hline France & 8.3 & 7.6 & 8.2 & 8.3 & 8.4 & 8.5 & 8.6 & 8.7 & 8.7 & 8.9 & & \\
\hline Germany & 11.3 & 10.8 & 10.9 & 11.1 & & & & & & & & \\
\hline Ireland & & 6.7 & 6.6 & 10.3 & & & & & & & & \\
\hline Italy & & 6.9 & 7.8 & 9.1 & 9.3 & 9.3 & 9.4 & 9.0 & 9.1 & 9.4 & 9.5 & 9.4 \\
\hline Japan & 8.2 & 7.2 & 8.1 & 8.2 & 8.5 & 8.7 & 8.8 & 9.0 & 9.2 & & & \\
\hline Netherlands & 8.6 & 5.9 & 5.6 & & & & 5.2 & 5.5 & 5.6 & & & \\
\hline New Zealand & 6.6 & 5.7 & 8.2 & 8.3 & 8.8 & 8.8 & 9.5 & 10.0 & 9.0 & & & \\
\hline Norway & 6.0 & 4.7 & 4.4 & 8.3 & 7.0 & 9.4 & 9.7 & 10.3 & 13.8 & 6.5 & 7.1 & 7.5 \\
\hline Portugal & & 4.3 & 7.2 & 9.1 & 9.7 & 9.0 & 9.1 & 9.6 & 9.8 & & & \\
\hline Spain & & 7.5 & 8.4 & 8.8 & 8.8 & 8.5 & 8.6 & 8.6 & 8.8 & & & \\
\hline Sweden & 6.2 & 4.1 & 4.4 & 6.0 & 6.0 & 5.7 & 5.5 & 5.7 & 6.3 & 6.6 & 6.9 & 7.1 \\
\hline Switzerland & 11.6 & 8.8 & 9.7 & & & & 9.6 & 9.9 & 10.1 & 10.5 & & \\
\hline United Kingdom & 7.1 & & 9.8 & 12.7 & 12.7 & 12.3 & 12.1 & 12.9 & 14.3 & & & \\
\hline United States & 7.8 & 8.2 & 13.0 & 16.5 & 15.4 & 14.6 & 14.9 & 16.1 & 17.4 & 18.0 & 18.3 & 17.7 \\
\hline
\end{tabular}

Note: The data in the first four columns relate to the nearest available year.

Source: Alvaredo, F., Atkinson, A. B., Piketty, T. and Saez, E. The Top Incomes Database, http://g-

mond.parisschoolofeconomics.eu/topincomes, 16/02/2011.

Source: Country delegate information: Australia (2000-2008), Canada (1970-2007), Italy (2005-2008), Netherlands (2003-2005),

Norway (1991-2008) \& Switzerland (1970-2006)

Roine, Jesper and Daniel Waldenström: Sweden (2007-2008)

17. The top percentile group experienced a bigger proportionate increase in its share than the top decile group in the period since 1990 in all countries but Japan - see figure A2.4 in annex 2. This phenomenon was particularly strong in Australia, Canada, the UK and US, but relatively modest in Belgium, France, the Netherlands, New Zealand and Switzerland. Within the top percentile group, the top $0.1 \%$ has tended to see the largest (proportionate) increase in their share of total pre-tax incomes. This has particularly been the case in the US and, to a lesser degree, Canada and the UK as the charts in annex 2 illustrate - see figure A2.3 in particular.

18. In the countries for which data are available, top income shares continued to rise during the economic expansion to 2007, but then fell back in 2008 with the start of the financial crisis and drop in stock markets. These developments point up a difficulty in interpreting data for the 2000s: what movements should be regarded as cyclical and perhaps therefore temporary? Interpretation of trends can also be clouded by other temporary factors such as the announcement of a tax reform that affects when income is declared for tax purposes - see, for instance, the spike for Norway 2004-2006.

19. Further information on changes in income shares of different fractile groups is set out in the charts in Annex 2. While all the caveats about international comparisons made above have to be borne in mind, they perhaps apply less strongly to changes in shares. Even so, changes in tax regimes may affect the measurement of income (as with the 'income shifting' in the US after the 1986 reforms) differently in different countries. That said, the scale of the rise in the share of the top $0.1 \%$ in the US stands out as being substantially larger than the rise in the corresponding share in other countries. 


\section{The characteristics of top income recipients}

20. The following sub-sections look in more detail at the characteristics of top income recipients, including the composition of their income, the taxes they pay on it, their occupations, their gender balance, their age, their wealth and how rapidly they move out of their top income group.

\section{The sources of income of top income recipients}

21. Figure 4 shows the series for the top $1 \%$ of income recipients with and without realised capital gains for the United States and Sweden. It shows that the inclusion of capital gains increases the share of the top $1 \%$. It also magnifies the increase in the share over the recent past. A similar pattern can be seen for the three other countries for which there are data with and without capital gains: Canada, Spain and Finland (Atkinson, Piketty and Saez, 2009). However, for Australia (2000-2008) and Norway (1993-2008) income including capital gains did not grow faster than income excluding capital gains, reflecting in part the fall in equity prices in the final year. There is, generally, more year-to-year variation in the time series for income including gains, reflecting not only stock market fluctuations but also timing effects from changes in tax rates on gains encouraging their realisation to be brought forward or postponed.

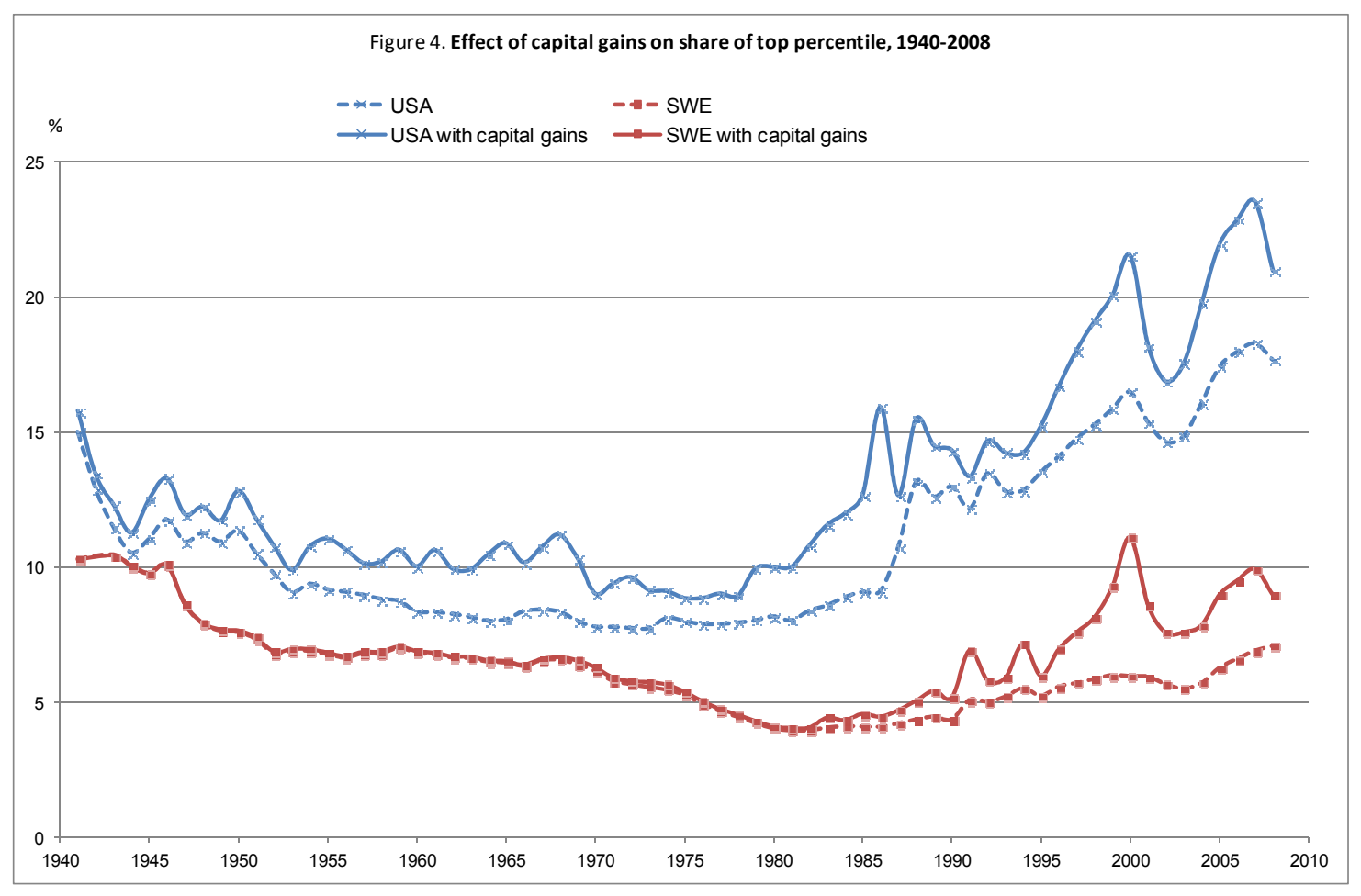

Sources: Sweden -Roine, Jesper and Daniel Waldenström (2008), "The Evolution of Top Incomes in an Egalitarian Society: Sweden, 1903-2004", Journal of Public Economics 92(1-2), 366-387

US - Alvaredo, F., Atkinson, A. B., Piketty, T. and Saez, E. The Top Incomes Database, http://gmond.parisschoolofeconomics.eu/topincomes

22. Turning to the shares of different income sources excluding gains, Piketty and Saez (2007) found for the United States that employment income, as well as self-employment income and closely-held business income that largely reflects employment income, now account for the vast majority of the incomes of top income recipients; and have also grown as a share of that income in recent decades, as 
shown in Figure 5. ${ }^{4}$ (It is worth noting that the realisation of stock options by corporate executives in the US is treated as wage income. Other points to note include the fact that gains are on a realisation basis and no estimate of the imputed rent from owner occupation is included in capital income.) Although data of this sort are not available for all countries, a similar shift in the composition of top incomes from capital income to earnings occurred in France (Piketty, 2003), Japan (Moriguchi and Saez, 2008), the Netherlands (Salverda and Atkinson, 2007), Canada (Saez and Veall, 2005), Italy (Alvaredo, 2010) and Spain (Atkinson, Piketty and Saez, 2009).

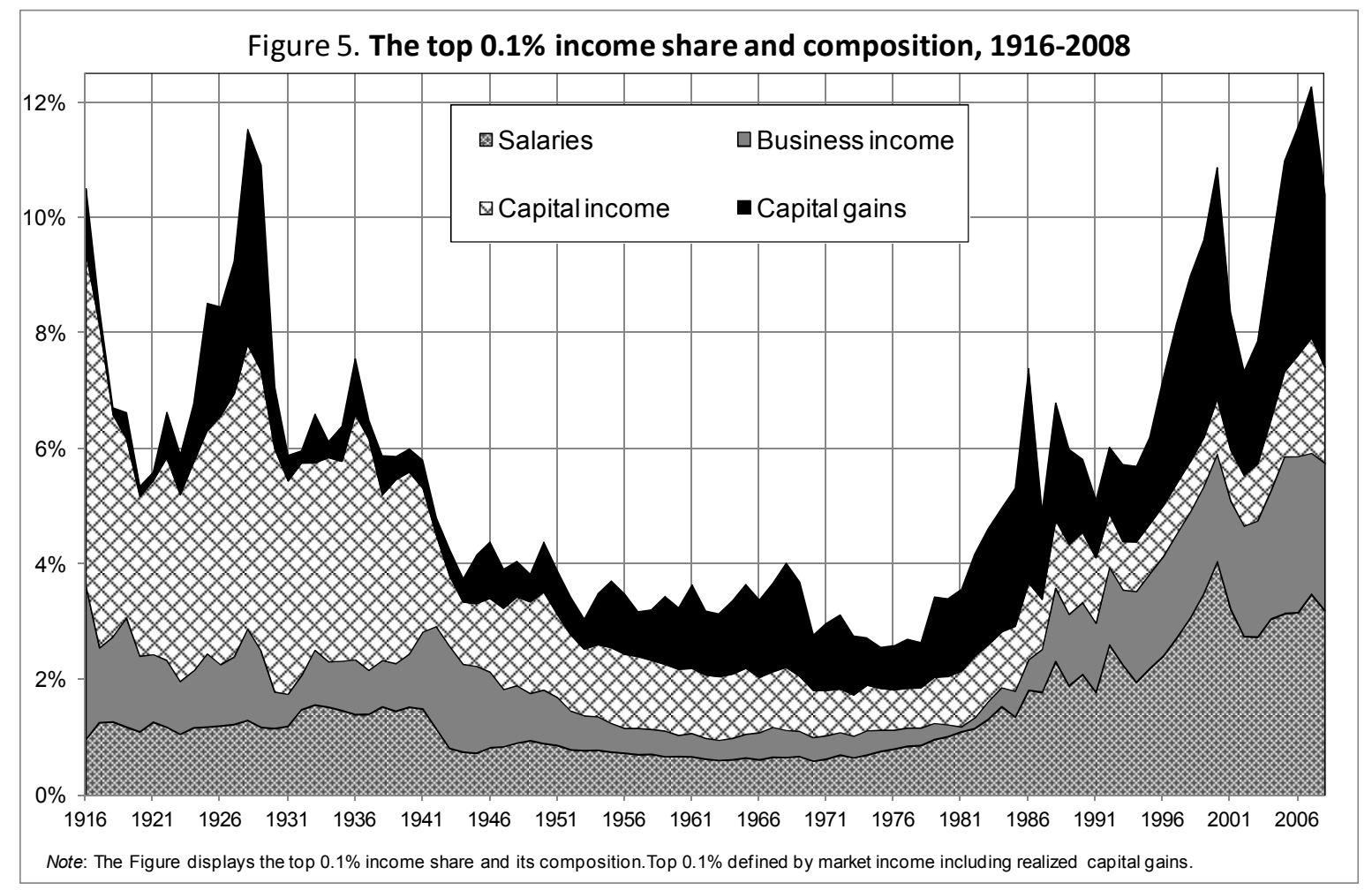

Source: Country delegate information

23. However, some countries have had a somewhat different experience. In Sweden (Roine and Waldenström, 2008), the wage share rose between 1945 and 1978 but has fallen back since. In Finland (Jantti et al., 2010), the share of capital income rose strongly after the mid-1990s. (This might in part reflect the adoption of dual income tax regimes in Scandinavian countries.) In Australia (Atkinson and Leigh, 2007), the share of salaries was almost unchanged over the last twenty years of the $20^{\text {th }}$ century.

24. In the United States since 1987 much of the growth of business income among top income recipients can be attributed to the increased use of 'pass-through' entities after the 1986 reforms, in order to take advantage of lower rates of personal income tax relative to the combined effects (under a classical corporate income tax regime) of tax at the corporate level and on dividends (and gains).

Even for the top $0.01 \%$ of income recipients in the US in 2005 , salary income and business income (i.e. selfemployment income, partnership income and S-corporation income) accounted for $80 \%$ of income excluding capital gains and $64 \%$ including gains, compared with $61 \%$ and $46 \%$ respectively in 1979 . See Bakja, Cole and Heim (2010) 
25. Employment income was the main force between the income growth of the top $1 \%$ in the United Kingdom (Atkinson, 2007b), while data in Alvaredo and Saez (2010) suggest that this is true also true of the top $0.1 \%$ and $0.01 \%$ in Spain but it is business income that is most important for the top $10 \%$ and $1 \%$. Also, Dell (2007) shows that wages and salaries grew as a percentage of the income of all top income groups in Germany between 1992 and 1998, and this trend is confirmed up to 2003 by Bach, Corneo and Steiner (2007).

26. In addition to looking at the evolution of income sources over time for the top income groups, it is worth noting the pattern of income sources across income groups. The general picture is that capital gains, capital income and business income make up a larger share of higher income groups within each country. However, there are exceptions, such as in Canada where capital gains are less important for the top $0.01 \%$ than for the top $0.1 \%$ and the labour income share is higher for the top $0.1 \%$ and $0.01 \%$ than it is for the top $1 \%$.

\section{Occupations}

27. Data on occupation of taxpayers are available for some countries. Table 2 underlines the importance of executives, managers and professionals in the top $0.1 \%$ group in the US (Bakija, Cole and Heim, 2010). The same paper also points up a sharp rise in the importance of financial professionals (up from $11 \%$ of the top $0.1 \%$ group in 1979 to $18 \%$ in 2004) and estimates that $70 \%$ of the rise in the share of the top $0.1 \%$ group between 1979 and 2005 went to executives, managers, supervisors and financial professionals.

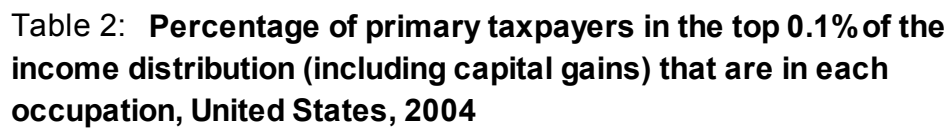

\begin{tabular}{|l|l|}
\hline \multicolumn{1}{|c|}{ Occupation } & $\%$ \\
\hline Executives, managers, supervisors (non-finance) & 41 \\
\hline Financial professions (including management) & 18 \\
\hline Not working & 6 \\
\hline Lawyers & 6 \\
\hline Real estate & 5 \\
\hline Medical & 4 \\
\hline Other & 20 \\
\hline
\end{tabular}

Source: Bakija, Cole and Heim, 2010

28. Corresponding figures for the top $0.1 \%$ of the distribution in Australia in 2008 show $36 \%$ of them are managers, $20 \%$ professionals and $34 \%$ retired or without employment.

29. Data for the UK suggests a picture similar to the US with regard to high incomes in the financial sector. Table 3 illustrates the extent to which high-earning managers and professionals are concentrated in certain sectors. 
Table 3. Taxpayers analysed by industry, United Kingdom, 2007-08

\begin{tabular}{|l|c|c|}
\hline \multicolumn{1}{|c|}{ Industry } & All taxpayers & Top 1\% \\
\hline Financial intermediation & 3.2 & 21.2 \\
\hline Real estate, renting and business services & 13 & 28.5 \\
\hline Other & 83.8 & 50.3 \\
\hline
\end{tabular}

Source : Survey of Personal Incomes 2007-08.

\section{Other characteristics}

30. A few countries produce breakdowns by sex. In the case of Australia, Canada and Norway about $80 \%$ of the top percentile of income recipients are men. This ratio has been declining slowly over time. In Sweden this ratio is substantially lower at about $55 \%$.

31. Data on age distribution of top income groups are available for Australia, Canada, Norway, Sweden and the United States. The data show a similar age profile for all countries - top income recipients are most likely to be in their 40s or 50s. In Australia, Canada and the United States, the modal age-group in the top $10 \%$ and $1 \%$ were in their $40 \mathrm{~s}$, but in the top $0.01 \%$ they were in their $50 \mathrm{~s}$.

32. For the most part the tax data sources that provide information on gross incomes do not also collect information of wealth, as it is not needed to administer the personal income tax regime. There may be data from estate or inheritance tax returns from which wealth estimates can be derived, or information may be collected via household income surveys, but it is not linked systematically to income tax data. This might be an area worth studying further in due course, as the relationship between income and wealth concentration may not be straightforward. For instance, the large increase in the share of top income recipients in the US does not appear to date to have been accompanied by increased wealth concentration see, for instance, Kopczuk and Saez (2004). Edlund and Kopczuk (2009) argue that there may have been a reduction in inter-generation wealth transfers ("dynastic wealth") broadly matched with a rise in self-made wealth (i.e. wealth accumulated by the successful entrepreneurs, top executives and professionals that account for a large part of the increased share of top income recipients in the US).

\section{Income mobility}

33. Most of the available income data derived from tax returns are cross-sectional. They show snapshots of the distribution of income at successive points in time. It is of considerable interest, though, to know whether, say, the top percentile group is always made up of the same people, or whether there is significant mobility in and out of this group. Indeed, it can be argued that there should be less concern about income inequality if there were a high degree of income mobility, allowing more people to enjoy the benefit of high incomes. On this view the policy implications of trends in income inequality should depend on the extent of the opportunity for upward mobility. If there is significant mobility upwards (and downwards) there is perhaps less obvious need for additional government intervention that goes beyond current policies.

34. A significant amount of mobility can be expected from such factors as the relationship between earnings and age (rising as work skills are developed, then falling at retirement), periods when individuals drop out of the labour markets to have and care for children, the effects of illness and unemployment, 
retirement decisions and the impact of fluctuations in stock markets on income from capital. Some mobility is thus a natural feature of most economies.

35. The extent of mobility can be expected to vary with the time period over which it is measured. Table 4 looks at turnover in the top percentile group from year to year. It shows data on the proportion of tax units who left the top income group (which can only occur if their relative income has fallen) were provided by delegates for Australia, Canada, Norway, and the United States. In all four countries, there was higher turnover in higher income groups with the Australia turnover rates in 2008 being around 30\% for the top $10 \%$ and around $67 \%$ for the top $0.01 \%$ and the corresponding numbers for the United States being $18 \%$ and $71 \%$. Overall, although the turnover rates vary, there was no clear time trend, with some tendency toward increased turnover in Norway and the US (in the case of the top 1\%).

Table 4. Turnover rates for the top 1\% (Exits compared with previous year)

\begin{tabular}{|c|c|c|c|c|c|c|c|c|c|c|c|c|c|c|c|}
\hline Year & 1994 & 1995 & 1996 & 1997 & 1998 & 1999 & 2000 & 2001 & 2002 & 2003 & 2004 & 2005 & 2006 & 2007 & 2008 \\
\hline Australia & & & & & & & & 38.6 & 37.8 & 36.9 & 36.1 & 35.6 & 35.5 & 37.1 & 38.7 \\
\hline Canada & 30.1 & 30.3 & 31.1 & 30.6 & 30.4 & 29.5 & 30.8 & 31.1 & 29.9 & 28.4 & 27.7 & 28.1 & 28.4 & 28.9 & \\
\hline Norway & 29.8 & 28.8 & 29.2 & 30.1 & 31.5 & 32.3 & 34.1 & 35.7 & 35.9 & 35.9 & 35.3 & 39 & 56.1 & 36.3 & 36.7 \\
\hline United States & 23.7 & 22.7 & 23.1 & 24.3 & 27.2 & 27.4 & 28.3 & 27.4 & 26.3 & 26.2 & 25.6 & 26.5 & 25.7 & 26.4 & 27.2 \\
\hline
\end{tabular}

Source: Data from country delegates

36. Given the dependence of an individual's income at any one point in time on age and particular life events that (s)he happens to be experiencing, one might ideally want to look at lifetime income and analyse whether lifetime incomes have become more unequal, or not. Panel data mostly do not follow the same individuals over a sufficiently long period of years to enable such a lifetime perspective. Some studies do, though, exist. For instance, a paper by Bradbury and Katz (2002) using the US Panel Survey of Income Dynamics for instance, suggests significant mobility across income quintiles over the 1970s, 1980s and the 1990s, but with a small decline in the extent of relative mobility in the 1990s.

37. The United States Internal Revenue Service has collected data over a large sample of taxpayers for more recent years including over-sampling of high income recipients, so the data should be more representative of such taxpayers than survey data (for the reasons discussed earlier in the paper). The data are for taxpayers rather than the total adult population, though the fact that some 90 per cent of working age adults file returns suggests that the difference may not be too material.

38. The data cover taxpayers over 25 (to avoid counting transitions from school or college to work as mobility). The primary and secondary taxpayers where a couple file jointly are followed (e.g. in the event of a divorce) and income is adjusted for family size (by dividing by the square root of the number of members of the household). Results for taxpayers who filed returns in both 1996 and 2005 are reported in Auten and Gee (2009). The broad measure of income that they use includes capital gains, though they say that the results were virtually the same whether gains are included or excluded from income. Their main findings are:

a) Taxpayers who filed returns in 1996 on average had moved up the distribution of the total taxpaying population of 2005, reflecting the entry of a new cohort of 25-34 year olds and immigrants with below average incomes.

b) If the potential for this source of upward movement in the income distribution is removed from the data by looking only at the same group of taxpayers who filed returns in both 1996 and 2005, the statistics still show considerable income mobility. For instance, over 60 per cent of taxpayers in the top percentile in 1996 had dropped down the distribution by 2005 .

c) In terms of real incomes (adjusted for family size) the median income of taxpayers in the panel in both years rose 23 per cent and two-thirds of taxpayers experienced an increase. 
However, the median income of those in the top percentile in 1996 had declined by some 30 per cent by 2005 .

39. Table 5 provides further statistical analysis of changes in the relative and absolute incomes of the top percentile group in 1996, further illustrating the transience of the composition of membership of this group. Nevertheless, looking at the very top of the distribution (the top 0.01 per cent, or some 12000 US taxpayers) while less than a quarter remained in this group by 2005,80 per cent stayed in the top percentile group. Perhaps in contrast to expectations, the real incomes of $60 \%$ of those in the very top group in 1996 had decreased by more than $50 \%$ by 2005 . Less than 40 per cent of the top percentile group in 1996 remained in this group in 2005.

Table 5. Income mobility of the top percentile group of United States Taxpayers 1996-2005

\begin{tabular}{|c|c|c|c|c|}
\hline \multicolumn{5}{|c|}{ Income mobility relative to total taxpayer population } \\
\hline 2005 & \multicolumn{3}{|c|}{1996 Income Group } & All income \\
\hline Income percentile & Top $0.01 \%$ & $0.01-0.1 \%$ & $0.1-1.0 \%$ & groups \\
\hline Top $0.01 \%$ & 23 & 3 & 0.3 & 0.01 \\
\hline $0.01-0.1 \%$ & 32 & 21 & 3.6 & 0.1 \\
\hline $0.1-1 \%$ & 27 & 38 & 31 & 1 \\
\hline $1-5 \%$ & 11 & 20 & 34 & 4.3 \\
\hline $5-10 \%$ & 0.2 & 3 & 9 & 5.5 \\
\hline $15-20 \%$ & 0.5 & 5 & 7 & 11 \\
\hline Below top 20 & 6 & 10 & 15 & 18.1 \\
\hline All & 100 & 100 & 100 & 100 \\
\hline \multicolumn{5}{|c|}{ Changes in real incomes adjusted for family size } \\
\hline$\%$ change & \multicolumn{3}{|c|}{1996 Income Group } & All income \\
\hline Real income & Top $0.01 \%$ & $0.01-0.1 \%$ & $0.1-1.0 \%$ & groups \\
\hline Fall more than $50 \%$ & 60 & 53 & 41 & 8.1 \\
\hline Fall $25-50 \%$ & 9 & 11 & 15 & 9.7 \\
\hline Fall up to $25 \%$ & 6 & 8 & 11 & 14.6 \\
\hline Rise up to $25 \%$ & 5 & 6 & 8 & 17.1 \\
\hline Rise $25-50 \%$ & 3 & 4 & 6 & 14.8 \\
\hline Rise $50-100 \%$ & 5 & 6 & 6 & 16.9 \\
\hline Rise over $100 \%$ & 12 & 12 & 13 & 18.9 \\
\hline Total & 100 & 100 & 100 & 100 \\
\hline
\end{tabular}

Source: Auten and Gee (2009) from IRS Statistics of Income.

40. Auten and Gee, (2009) go on to compare the degree of relative income mobility over the 19962006 period with the previous decade (1987-1995) and find virtually no change in relative mobility. The only significant difference between the two periods was a decline in downward mobility for those in the top income quintile but below the top $1 \%$ in the initial year. The results indicate that larger changes in absolute incomes were sufficient to offset wider income gaps and keep relative mobility unchanged. They also find that changes in mobility of after-tax incomes are similar to those in pre-tax incomes.

41. Saez and Veall (2005) found similar results for Canada using a panel of longitudinal data going back to 1982. Income mobility (looking at 1, 2 and 3 year periods) has been broadly unchanged over time, with, if anything, a slight tendency to decline over time.

\section{Conclusions}

42. This section has pointed up the remarkable increase in the share of top income recipients in total income over the past three decades in the US, but also noted that there is a continuing turnover from one year to the next and one decade to the next in the individual taxpayers who make up the top income groups. Other countries have seen smaller increases in the shares of top income recipients in total income. These increases have been largest in a number of other English-speaking countries (Australia, Canada, and the UK) than elsewhere; and the increases have been much more modest in Continental European countries and top income shares (except perhaps at the very top of the distribution) have been broadly unchanged in a few of these countries. 
43. Importantly for the discussion of the explanation of these trends in the next section, the greater part of these increases in top incomes are attributable to rising employment and business income. Most data are available for the US and UK and they show that it is the rising incomes of executives and (finance) professionals that account for much of the rising share of top income recipients. Data for the US, Canada and a handful of other countries suggest that mobility into and out of the top income fractiles has been broadly stable, or decreased slightly.

\section{Explanations of the trends in top incomes}

\section{Introduction}

44. There are three major trends in the top income data. The first is a decline of top income shares that took place over the first three-quarters of the last century. The second is a period of relatively stability in the top income share from the 1950s through the 1970s. Thirdly, there has been an increase in top income shares in all but a few OECD countries over the last two to three decades.

45. Atkinson, Piketty and Saez (2009) suggest that the initial decline of top income shares was probably due to a combination of factors:

- The destruction of capital during the two world wars, plus the effects of wartime inflation and controls over prices and rents.

- The equalisation of earned income during the Second World War, at least partly as a result of wartime wage controls.

- The loss of wealth in the financial crisis of the 1930s.

- The large extension of progressive income taxation and taxation of inheritances made it more difficult for the rich to maintain their wealth.

46. Turning to the more recent increases in top income shares, countries have differed substantially in the timing and extent of their increase in top incomes. Any overall explanation of the trends must consider what has changed since the first three decades after the Second World War (when high growth rates were combined with no marked trends in top income shares) and more recent years. Explanations must also allow for different factors acting in different countries and/or for the response of different economies to common factors being different because of differences in economic structures. These differences are one of the reasons why the causes of changes in both overall inequality and top income shares are still subject to disagreement. That said, the story underlying the big increases in top income shares in many countries is primarily about employment (and business) income. This is particularly the case in the United States, where the biggest rise in the share of 'top incomes' has occurred.

47. Analysis of causes in trends in the distribution of income is in any case likely to be contentious, especially given the scale of the increase in the share of top incomes in some countries in recent years. The role of tax cuts had been particularly controversial. Does the rise in top incomes share reflect a real response to improved incentives through increased effort, entrepreneurship, etc? Does a significant part of the rise in the chosen measure of income simply reflect income-shifting and other tax planning responses to tax changes? Or are there drivers that are unrelated to tax changes that have increased the share of top incomes irrespective of what happened to tax regimes and rates?

48. At this stage, it is only possible to discuss different factors that could form part of an overall explanation without coming to any conclusion about their relative importance. The factors, which will be discussed in turn, are: 
a) The substantial reduction in top rates of personal income tax.

b) The effects of 'supply and demand' factors such as increased international trade, globalisation and skill-biased technical change on the relative wages of skilled and unskilled workers, including on the incomes of 'stars'.

c) Changes in the way that labour markets function, notably the erosion of pay norms.

d) Factors influencing the remuneration of top executives and finance professionals, e.g. performance-related pay, stock markets and corporate governance

\section{The effects of reductions in tax rates}

49. There are a number of ways in which lower tax rates could lead to increases in top income shares, including: (i) changes that have little effect on the 'real' economy such as tax planning that leads to more income taking the form of personal income (and less as, say, corporate income) or a reduction in tax evasion, (ii) an increase in work effort and entrepreneurship, and (iii) an increased ability of high earners to accumulate wealth.

50. Distinguishing between the first two of these effects can be difficult, while the third cannot readily be measured directly.

\section{Evasion}

51. In the case of tax evasion, lower tax rates in principle reduce the financial benefits of such behaviour, i.e. the amount of tax saved. Inevitably, though, there is little direct evidence on the scale of evasion - at best only its 'shadow' can be observed. And the scale of evasion will depend on other factors such as perceptions of the risk of detection, the financial penalty and social stigma if tax fraud is detected, the availability of (third party) information to the tax authorities to verify taxpayers' information, and so on. Overall, tax authorities judge the scale of tax evasion (and more aggressive forms of tax avoidance) to be significant and perhaps to have grown (perhaps assisted by globalisation) notwithstanding the effects of lower statutory tax rates. This has been a driver of the moves under OECD auspices to improve exchange of information for tax purposes. The latest information on the OECD's work on this is contained in the 'Istanbul Communiqué' (www.oecd.org/dataoecd/18/25/46026232.pdf).

\section{Elasticities of taxable income}

52. Meghir and Phillips (2010) provide a comprehensive and authoritative recent review of the literature on the effects of tax on labour supply. Much of this work has focused on people of average or below-average incomes. However, some has dealt with people on high incomes. There are two particular difficulties in analysing the effect of income tax on high income individuals. First, the main variation in their work is not their labour market participation or their recorded hours of work; it is the effort that they put into their work. This means that there is little to be learnt from looking at how their hours of work respond to taxes, and it is necessary to look at the income they earn instead. Second, high income workers find it easier than most to avoid tax on their income; so there is a difficulty in using taxable income as measure of effort and one should look at a broad measure of gross income, as well as taxable income - as discussed further in section 5 below.

53. Because of the first difficulty, the behavioural effects of a change in tax rates are obtained by estimating equations that try to explain changes in income by changes in marginal tax rates. In fact, the equations typically use the share of income retained ( 1 - marginal tax rate) instead of the actual marginal tax rate. The key parameter that is estimated is the elasticity of income with respect to the share of income retained, which is a positive number. 
54. Meghir and Phillips provide a table of results from a number of studies, but the study that they regard as best is Gruber and Saez (2000), which uses data from the United States from 1979 to 1990 and so analyses the effects of the 1981 and 1986 tax changes. For the population as whole, they estimate elasticities for two different income concepts: (i) a 'broad income' definition that includes items of income that are untaxed, and (ii) a narrower taxable income (which takes off the deductions that taxpayers claim in preparing their tax returns). The elasticity with respect to broad income is 0.12 and the elasticity with respect to taxable income is 0.4 . They also estimate elasticities of taxable income separately for high income and low income individuals. For the high income, it is 0.57 and for the low income it is 0.18 .

55. In addition, their results for taxpayers with incomes in 1979 above USD 100,000 suggest that while their elasticity of broad income is slightly higher than for the population as a whole ( 0.17 compared with 0.12 ), their elasticity of taxable income is substantially higher $(0.57)$. In other words, people on higher incomes engage in more tax planning (as a proportion of their income) and this tax planning responds to marginal tax rates. ${ }^{5}$

56. A particularly pervasive form of tax planning has been through shifting of business income into a form in which it is more lightly taxed, e.g. through the adoption of a business form that exploits differences between personal and corporate income tax rates. This might make it financially attractive either to incorporate or to use a 'pass-through' entity, depending on the specific circumstances. In the US the use of 'pass-through' arrangements has grown massively since the 1986 tax reform brought personal tax rates below those on corporations. (About half of business income is now in pass-through form compared with about a quarter in the early 1980s, chart 3.1 in Department of the Treasury (2007).)

57. Another piece of empirical work, by Atkinson and Leigh (2010), also finds significant effects of tax changes on top incomes. It analyses and compares top income shares for Australia, Canada, New Zealand, the United Kingdom and the United States. Using these data as a panel from 1970 to 2000, they estimated the relationship between the shares of the top $1 \%$ in these countries and the marginal tax rates, using country fixed effects to control for (constant) differences between countries and year fixed effects to capture non-tax factors that affect these shares (which are assumed to have the same effect in each of these countries). They conclude that the changes in tax rates over this period can account for between one third and one half of the increase in the shares of the top $1 \%$ in these countries.

58. Thus, as top marginal tax rates have fallen over the last 30-40 years, income shifting and other forms of tax planning could be part of an explanation of the increased share of reported top incomes and of the fact that the highest income groups have experienced the greatest increase. However, the nature of the data means that the differences in taxable income elasticities cannot be used to estimate precise distinctions between 'tax planning', evasion or 'real' behavioural effects.

59. That said, there is evidence that there are real responses (such as increased work effort and entrepreneurship) to tax rate changes and not just changes to reporting of income for tax purposes. The study by Gruber and Saez (2002), for instance, shows that broad income (i.e. a measure of income less subject to tax planning effects) does respond to changes in the marginal tax rate and suggests that this effect is higher for people in higher income groups. However, the continued rise in the shares of top income recipients in the US after top personal tax rates were increased in 1993 suggests that other (nontax) factors have also been important.

5 The difference between broad income and taxable income does not entirely escape tax. For example pension contributions will typically reduce current taxable income but will increase taxable income when the pension is finally received. Also, income that accumulates in companies will be subject to corporate tax. 


\section{Increased wealth accumulation}

60. The fact that top marginal rates of personal income tax have fallen in OECD countries over recent years (and in many countries taxes on property and inheritances have also fallen) implies that top income groups are able to keep a higher proportion of their income. This means that it is easier for rich people to accumulate wealth, and this could lead to increases in their capital income in the future. The little available data on wealth presented above suggests that wealth may be becoming more concentrated in the highest income groups.

61. It is hard to tell whether this process has yet contributed to the observed increase in top income shares since 1970, especially as in most countries for which data were available, the increase in the share of top incomes is associated with a increases in labour income, rather than capital income. However, the Netherlands, Sweden and the United States saw some increase in the share in capital income in total income at the top of the income distribution in the 2000s and capital gains have become a more important part of the income of top income groups in most of the countries for which data are available. Nevertheless, the world is very different from the pre-1940 period when the share of top incomes was even higher and those incomes consisted primarily of capital and rentier income.

\section{The effects of globalisation and skill-biased technical progress}

62. One of the most popular explanations of the general increase in inequality is that the greater participation of low-wage economies in international trade has reduced the world prices of goods that are relatively intensive in low-skilled labour. Another is that technical change over the last few decades, particularly the widespread use of computer technology, has been skill-biased in the sense that it has increased the relative demand for skilled labour. This, it is argued, has increased the relative wages of skilled to unskilled workers. As this explanation works through the same mechanism - relative wages - as the international trade explanation, it can be difficult to distinguish the two empirically.

63. However, even if this is a partial explanation of increases in overall inequality and of the increase in the income of the top decile point relative to the rest of the population, it may not provide much explanation of trends within the top decile group, notably the increased concentration within this group in many countries (as illustrated by the trends for the top $0.1 \%$ and top 0.1 to $1.0 \%$ groups in figures 10 onwards in annex 2). The top $10 \%$ group of income recipients is unlikely to include many unskilled workers, so theories that seek to explain skilled/ unskilled relative wages cannot explain the redistribution that has taken place within this group.

64. Other (perhaps more subtle) changes may have increased skill premiums within the top decile group. The idea that 'stars' - people who are regarded as the very best in their profession, even if it is not in entertainment or sport - have their earnings determined in a particular way has a long history in labour economics. The basic idea is that employers of 'stars' are not simply interested in the absolute quality of the workers they hire but also their relative quality. In other words, they want to hire the best workers. This can be observed in the entertainment industry, where there is a large difference in incomes between the most popular entertainers and those that are just a little bit behind them in terms of ability.

65. Atkinson (2008) argues that the improvements in information technology and the growth of trade has meant that the market for 'stars' has become global. Employers don't just want the best person in their country; they want the best person in the world. This means that the demand for these stars around the world is focussed on a smaller number of 'global stars', whose earnings have increased enormously compared to 'national stars'. This is an interesting theory with some empirical support, and may provide some explanation of why the incomes of the top $0.1 \%$ or even the top $0.01 \%$ have increased more rapidly 
than top income recipients as a whole, especially when taken together with the changes in performancerelated pay discussed below.

66. International linkages between labour markets may in some cases be more extensive than the market for 'stars'. For instance, very high-skilled Canadians have the option of going to work in the US, especially after 1995 when the North American Free Trade Area (NAFTA) allowed highly skilled workers to get US work visas more easily. Saez and Veall (2005) see such mobility as having a significant causal influence on the increased share of top income recipients in Canada. They note that the there is less need to pay high salaries in Canada to retain francophone Canadians and that there has indeed been a more modest rise in the top shares in Quebec. The mobility of high-skilled workers could also be a factor in explaining trends in other countries such as New Zealand.

\section{Changes in labour markets}

67. There have been substantial changes in labour market policies and institutions over the past 30 years or so, including declines in unionisation, a reduced role for collective bargaining, and variations in minimum wages and social security safety-nets in relation to average wages. Many of these are unlikely to have much direct effect on top incomes. Nevertheless, there are two factors that deserve particular attention: the growing use of performance-related pay and changes in pay norms. The former is considered further in the next section, the latter in the next paragraph.

68. The idea that pay norms affect wage differentials has a long history in labour economics, even though it is not compatible with simple competitive theory. As noted above, wage compression during the Second World War is likely to have been one of the factors that reduced the share of top earners in the middle of the last century. Atkinson (2008) argues that pay norms that used to limit wage differential have been eroded over the past few decades and he sets out a model in which the way in which norms are determined could result in there being two distinct equilibria: one with modest wage differentials and the other with more substantial differentials. He argues that this can explain some of the large increases in the incomes of top salary earners.

\section{Remuneration of top executives and finance professionals: performance-related pay, stock markets and corporate governance}

69. This section focuses primarily on experience in the US where the particularly large increases in the shares of top income recipients and the important part played by the remuneration of top executives (and finance professionals) has naturally attracted attention. There is evidence from the labour economics literature that increases in earnings inequality have been 'fractal' in nature - almost regardless of how a group is defined (including by occupation) earnings inequality has increased within that group (e.g. see the survey by Levy and Murnane (1992)). This is also evident in the data on the incomes (by occupation) in the top income groups. Large divergences in the growth of incomes of people in the same profession suggests that they are not just being affected by common trends but also that mechanisms are at work that accentuate differences. One such mechanism has been the growth of performance-related pay.

70. Lemieux, MacLeod and Parent (2007) analysed data for the United States and showed that the spread of performance-related pay can explain about a quarter of the growth in the variance of male wages between the late 1970s and early 1980s. They claim that it accounts for nearly all of the growth in wage dispersion in the top $20 \%$ of labour incomes. As increasing top labour incomes have been a major component of the increase in the top income shares, it appears that this could be a substantial explanation of recent trends. Performance-related pay has grown particularly strongly in the United States but it is spreading to other countries, partly in an attempt to attract internationally mobile workers. 
71. The form of remuneration can perhaps be regarded as to some degree a proximate cause. It prompts questions about what factors have driven businesses to change their remuneration policies in this way. Implicitly, there is a presumption that there must be increased competition for highly skilled executives and finance professionals, but what lies behind this? Similarly, given that the performance element in remuneration has often taken the form of stock options, is this an effective way of aligning the interests of (top) employees and shareholders and thus of improving incentives to make businesses more efficient and profitable? Or is it, in effect, a sign that managerial discretion has enabled managers to siphon off more profits? Related corporate governance issues are the processes through which top executives and finance professionals have seen much faster growth in their incomes than average pay rates: are boards of directors sufficiently rigorous about setting the remuneration of their executive colleagues, for instance?

72. One consequence of the gearing of top executives' pay to equity prices through remuneration in the form of stock and stock options is that the share of top income recipients in total income is likely to be more closely correlated with equity prices than in the past. This is indeed consistent with such facts as the dips in the share of top income recipients after the stock market peaks of 2000 and 2007 - see figure 1 above. This is particularly the case for measures of income that include gains. Unsurprisingly therefore, data for the US for 2008 indicate a fall in the share of top income recipients. How far subsequent developments such as increased regulatory capital requirements for banks (which is likely to reduce their profitability) and the increased use of deferred bonuses will impact on the share of top income recipients in future remains to be seen.

\section{Conclusions}

73. While some of the increase in the share of top income recipients of total pre-tax incomes can be explained in terms of changes in the reporting of income for tax purposes, notably in the US, this can only be part of the explanation. Countries have differed in the timing and scales of their tax reductions and the extent to which income-shifting (leading to more income being reported) is practicable or worthwhile. Even in the US the surge in the share of top income recipients continued in the US when top marginal tax rates were raised.

74. Among non-tax factors, competition for top executives and finance professionals appears to have played a significant role in raising the shares of top income recipients, at least in the countries that have seen the biggest increases in top income shares such as the US, Canada and the UK. (This phenomenon does not appear yet to have been much investigated in other countries.)

\section{Tax Policy Implications}

\section{Introduction}

75. In some countries top income recipients are now quantitatively very important for government tax revenues. In the US the top percentile group of taxpayers paid $40 \%$ and the top $5 \%$ paid $60 \%$ of federal income tax in 2005 (IRS data reported in Mudry and Bryan, 2009). Similar distributions occur in other countries, although perhaps to a less marked degree. For instance, in the UK the top $1 \%$ of taxpayers paid some $24 \%$ of personal income tax in 2006-07 (HMRC statistics).

76. Where the share of top income recipients' share of gross personal incomes has risen, it may be worth considering whether taxes could (or should) be increased for these taxpayers in order to take advantage of the apparent increase in their 'ability to pay' to raise more tax revenues; and perhaps also to make the distribution of after-tax income less unequal. Accordingly, this section looks first at the extent to which top income recipients are already taxed and at how post-tax income shares compare with the pre-tax 
shares considered so far in this paper. It then reviews how top marginal rates of personal income tax have evolved over the past 30 years.

77. The desirability of increasing the average tax burden on top income recipients depends on a number of factors, including the reasons for the increase in their share of pre-tax incomes, value judgements about how socially undesirable inequality is, how an increase in average tax rates is achieved and on an assessment of the economic harm that might result. This section considers the pros and cons of raising marginal personal income tax rates, and includes a brief review of the evidence on taxable income elasticities (particularly for the US) that has been produced in recent years. It then looks at other options for raising additional tax revenues from high income recipients such as reducing the value of tax reliefs and tax expenditures, changes in the treatment of capital gains, and increased taxation of property.

\section{The effects of taxes on top income recipients}

78. The data presented and analysed so far in this paper have been for pre-tax incomes. If the personal income tax (PIT) regime is progressive (i.e., average tax rates rise with income) the share of top income recipients in post-PIT income will be smaller. Personal income tax schedules are almost always designed with ability to pay (as well as economic efficiency) in mind and the practice of exempting a large initial slice of income from tax means that the average tax rate rises with income. This is often combined with some rise in the marginal tax rate applied to successive income bands. In a simple two-rate structure, for instance, the first band of taxable income might be taxed at, say, $20 \%$ and any income in excess of this taxed at, say, $40 \%$. Table 6 shows the extent to which average personal income tax burdens rise with income in the US, France and the UK. For all three countries there is a marked degree of progressivity within the top percentile group (with some variation from country to country).

Table 6. International comparison of average PIT rates

\begin{tabular}{|c|c|c|c|}
\hline & $\begin{array}{c}\text { United States } \\
(\mathbf{2 0 0 4 )}\end{array}$ & $\begin{array}{c}\text { France } \\
(\mathbf{2 0 0 5})\end{array}$ \\
\hline Full population & 11.5 & 3.8 & $\begin{array}{c}\text { United Kingdom } \\
\mathbf{( 2 0 0 0 )}\end{array}$ \\
\hline Percentile $0-90$ & 5.4 & 1.8 & 15 \\
\hline $90-95$ & 11.6 & 4.5 & 15.7 \\
\hline $95-99$ & 16.4 & 7 & 21.7 \\
\hline $99-99.5$ & 21.4 & 11.6 & 27.7 \\
\hline $99.5-99.9$ & 23.8 & 16.4 & 30.5 \\
\hline $99.9-99.99$ & 25.1 & 22.3 & 33.2 \\
\hline $99.99-100$ & 26.2 & 28.8 & 34.5 \\
\hline
\end{tabular}

Source: Piketty \& Saez (2006)

79. Average tax rates applied to the top percentile group of income recipients in other countries are generally higher than in the US, as Table 7 indicates. (Figures are for PIT only) and suggests that over the past decade average effective PIT rates on the top percentile group have tended to fall. 
Table 7. Average personal income tax burdens on top percentile group

\begin{tabular}{|c|c|c|c|c|c|c|c|c|c|c|}
\hline Year & 1990 & 2000 & 2001 & 2002 & 2003 & 2004 & 2005 & 2006 & 2007 & 2008 \\
\hline Australia & n.a. & 33.1 & 39.7 & 39.2 & 39.6 & 40.0 & 39.9 & 39.0 & 37.2 & 37.9 \\
\hline Belgium & 38.6 & 41.5 & 41.5 & 37.9 & 36.3 & 35.5 & 35.8 & 35.3 & n.a. & n.a. \\
\hline Canada & 38.3 & 39.7 & 35.9 & 35.3 & 35.4 & 35.3 & 35.6 & 35.5 & 35.0 & n.a. \\
\hline Denmark & 59.5 & 47.2 & 48.3 & 48.3 & 47.8 & 46.1 & 46.5 & 44.2 & 46.9 & 43.8 \\
\hline Italy & n.a. & n.a. & n.a. & n.a. & n.a. & 35.9 & 35.1 & 35.5 & 36.6 & 36.4 \\
\hline Netherlands & n.a. & n.a. & n.a. & n.a. & 32.0 & 32.9 & 33.8 & n.a. & n.a. & n.a. \\
\hline Norway & 26.2 & 29.9 & 33.7 & 21.2 & 20.0 & 20.7 & 17.5 & 39.4 & 39.2 & 33.5 \\
\hline Sweden & 32.5 & 37.4 & 38.2 & 36.6 & 36.4 & 37.3 & 37.4 & 35.7 & 33.5 & 32.3 \\
\hline United States & 25.3 & 36.6 & 32.4 & 30.5 & 28.1 & 28.9 & 29.9 & 30.2 & 30.5 & 27.5 \\
\hline
\end{tabular}

Note: The data in the first column for Norw ay and Sw eden relates to 1993 data. Source : Data from country delegates

80. However, looking at the effects of PIT by itself gives an incomplete picture of the potential redistributive effects of direct taxes. Social Security Contributions (SSCs) tend to be much less progressive. Indeed, there is often a ceiling on contributions, so that they effectively become a lump sum tax for top earners (and are thus regressive at these income levels). However, depending on the strength of the relationship in a country between contributions paid and benefits received, SSCs may be less regressive when considered in the perspective of an individual's lifetime. On the other hand, wealth taxes levied on the fortunes of the very rich could be very progressive and should in principle be considered alongside PIT in assessing the progressiveness of a tax regime.

81. Overall, the share of top income recipients in post-tax income is smaller than their shares of pretax income. This is the case even where (as in Piketty, T. and E. Saez, 2006), allowance is made for other direct taxes, e.g. payroll taxes, estate duties and corporate taxes, as well as PIT. Their estimates for the US for 2004 (which are on such a basis) are set out in Table 8 below.

Table 8. Share of pre- and post-tax income in the United States, 2044

\begin{tabular}{|c|c|c|}
\hline & Pre-tax income share & Post-tax income share \\
\hline Percentile $0-90$ & 53.75 & 57.28 \\
\hline $90-95$ & 11.29 & 11.07 \\
\hline $95-99$ & 15.28 & 14.51 \\
\hline $99-99.5$ & 4.11 & 3.69 \\
\hline $99.5-99.9$ & 6.63 & 5.8 \\
\hline $99.9-99.99$ & 5.46 & 4.69 \\
\hline $99.99-100$ & 3.48 & 2.96 \\
\hline
\end{tabular}

Source: Piketty, T. and E. Saez, 2006.

\section{Top marginal income tax rates}

82. While the overall PIT structure in a country will affect how much tax top income recipients pay, the top marginal rate of tax is likely to be particularly significant for them. Table 9 summarises the history of top rates in major OECD countries over the past 30 years. 
Table 9. Top marginal rates of central government pesonal income tax ( \%)

\begin{tabular}{|l|c|c|c|c|}
\hline & 1981 & 1990 & 2000 & 2010 \\
\hline Australia & 60 & 47 & 47 & 45 \\
\hline Canada & 43 & 29 & 29 & 29 \\
\hline France & 60 & 57 & 53 & 40 \\
\hline Germany & 56 & 53 & 51 & 45 \\
\hline Italy & 72 & 50 & 49 & 43 \\
\hline Japan & 75 & 50 & 37 & 40 \\
\hline United Kingdom & 60 & 40 & 40 & 50 \\
\hline United States & 70 & 28 & 40 & 35 \\
\hline
\end{tabular}

Source: OECD (Data from country Delegates).

83. There has thus been a marked fall in top marginal PIT rates ${ }^{6}$. In some countries much of this reduction occurred in the 1980s (Australia, Canada, Italy, Japan, UK and US), but in some countries (e.g. France and Germany) governments made more modest and gradual reductions. It is worth noting that those countries that made the bigger and earlier cuts also saw bigger rises in the shares of top incomes, though (as discussed above) the scale of any causal relationship remains unclear.

84. Average tax burdens are naturally below top marginal tax rates, reflecting not only the standard personal allowances and lower rate tax bands, but also other tax reliefs and tax expenditures (e.g. for mortgage interest relief, saving in pension funds and charitable deductions).

\section{Effects of raising marginal personal tax rates}

85. Two key issues when looking at the redistributive effects of an increase in marginal tax rates are whether this directly increases progressivity and how much additional revenue would be raised. ${ }^{7}$ The key parameter for estimating the additional revenue is the elasticity of tax revenue to changes in the marginal tax rate faced by those on top incomes. This parameter is also the key to estimating the distortionary effect (efficiency reduction) of any tax change, as it captures both the reduction in work effort and the increase in the diversion of resources to (socially wasteful) tax avoidance and evasion (on the assumption that people chose their level of these activities in order to maximise their personal utility). ${ }^{8}$

6 But note that these are central government rates and in some countries there have been increases in tax rates at sub-central levels. For instance, Saez and Veall (2005) estimate that after the initial reduction in the early 1980s the marginal tax rate in Canada (more specifically Ontario) including provincial tax for the top $0.1 \%$ of the distribution remained broadly unchanged at around 50\% for the rest of the 1980 s and 1990s.

7 Additional revenues could potentially be redistributed to people with lower incomes through tax cuts, incomerelated tax credits or public expenditure on benefits.

8 This reasoning was originally developed by Feldstein (1995). However, it has been recently challenged by Chetty (2009), who argues that this overstates the social cost of tax planning because some individuals overestimate the costs of tax planning and some of those costs represent transfers to tax planners rather than the use of scarce resources. These considerations would reduce the distortionary cost of increasing marginal tax rates. 
86. Estimates of this elasticity of taxable income (ETI) are obtained by estimating equations that try to explain changes in taxable income by changes in marginal tax rates. Estimation is a difficult task as tax rates are to some degree endogenous. This is why researchers have focused on episodes such as an (unexpected) tax reform that produces an exogenous change in marginal tax rates. It is also important to control for a range of other factors that can also give rise to spurious results. Unsurprisingly, there have been wide variations in estimated elasticities (Saez, Slemrod and Giertz, 2010).

87. Gruber and Saez (2000) estimate for the US elasticities with respect to the tax rate of 0.12 for 'broad income' and 0.4 for taxable income, with an estimate for the latter of 0.57 for high income recipients and 0.18 for low income recipients.

88. In order to obtain some intuition about what these numbers mean, consider a hypothetical example in which a marginal tax rate of $50 \%$ is increased to $51 \%$, the proportionate reductions in income would be:

i. $\quad$ For broad income (elasticity $=0.12), 0.24 \%$.

ii. For taxable income (elasticity $=0.4), 0.8 \%$

iii. For high income people (elasticity $=0.57), 1.14 \%$

iv. For the low income people who might, say, have a high marginal effective tax rate because of the income-related withdrawal of tax credits (elasticity $=0.18), 0.36 \%$

89. In the case of a high income individual, the additional tax paid would be slightly less than half the amount had there been no behavioural response, if the higher rate of tax applied to the entire person's income. If, however, the higher tax rate applied to only half the person's income (e.g. because of increasing marginal tax rates), no additional tax would be paid.

90. These estimates suggest that increasing marginal tax rates on high income individuals would reduce their taxable income substantially, and so may collect little or no extra revenue to redistribute to people on lower incomes. In addition, the comparison between elasticities for the broad income and the taxable income suggest that there could also be significant 'real' effects.

91. However, elasticity estimates for different time periods and different countries may differ:

1. Countries differ considerably in their estimated elasticity of taxable income. For example, Saez et al. (2010) report a study of Denmark that concluded that the elasticity there is substantially lower than that found in other countries. Holmlund and Söderstrom (2007) estimate an elasticity of 0.29 for top income recipients in Sweden. However, Brewer, Saez and Shephard (2010) report a range of elasticities for the United Kingdom, depending on the controls used, of between 0.46 and 0.73 for the period 1962-2002. A recent Canadian study, Department of Finance (2010) that reviewed the international empirical literature found a central ETI estimate to be around 0.4, but with significantly higher ETIs for taxpayers on very high incomes. In the case of Canada, new empirical estimates implied somewhat lower estimates - an ETI of 0.2 for the top $10 \%$ of taxpayers overall, but an ETI of over 0.6 for the top percentile group.

2. Saez, Slemrod and Giertz (2010) compare studies from the US for different time periods and conclude that as the 1986 tax reforms reduced the availability of tax deductions and exemptions, the elasticity will have fallen. Tax elasticities thus depend on the scope that tax law gives for tax planning. 
3. Estimates of the effects of a change in PIT rates on receipts should ideally make allowance for the effect on other tax bases due to income-shifting and timing effects (e.g. higher PIT rates may mean some increase in receipts from taxes on capital gains or corporate income), but often this is not practicable. This may mean that estimates may overstate the net overall reduction in tax payments that results from tax planning, and hence understate the net receipts from increasing tax rates.

4. There may be variations in the extent to which the incomes of top earners include an element of economic rent, the taxation of which would have little effect on effort. Some argue, for instance, that the remuneration of top executives and financial sector professionals includes a significant element of economic rent.

5. International mobility of high income individuals may be more of an issue for some countries than others. For instance, the responsiveness of top income recipients in English-speaking countries to differences in after-tax pay compared with the US may be greater than for other top income recipients. Such international mobility would also imply that the location specific element of any economic rent in the earnings of top executives and financial sector professionals might be relatively small in practice.

92. These considerations suggest that countries need to undertake a thorough analysis before deciding on the advantages and disadvantages of increasing top marginal tax rates.

\section{Raising average tax rates by reducing tax expenditures}

93. The high ETIs of top income recipients (absolutely and relative to the rest of the population) indicated by the empirical literature and the tax planning and avoidance opportunities open to these individuals, points up the need to reduce these opportunities if additional tax revenues are to be raised from top incomes. Measures that achieve a higher average rate of tax on top income recipients without also raising their marginal rate would enable more redistribution, with less unwanted distortion of labour supply and 'effort'. An example of the type of reform that could achieve this would be imposing restrictions on the amount of relief that can be claimed for mortgage interest or charitable donations. For instance relief could be provided at less than the top marginal tax rate, or the maximum tax saving (in dollar terms) could be capped. Such restrictions are likely to bear more heavily on high income than middle/ low income taxpayers. Thus it should be possible to increase average tax rates on top income recipients (i.e. the rate most pertinent to revenue raising and redistribution) while not raising marginal rates for most of those affected (i.e. the rates most pertinent to economic distortions). OECD (2010a) provides further discussion of the 'Choosing a Broad-Base Low-Rate Approach to Taxation'.

\section{Taxation of capital income}

94. Notwithstanding the important part played by the increase in employment and business income in driving the growth in the share of top income recipients in many countries, the top fractile groups continue to have proportionately more capital income than the rest of the population. Increased taxation of capital income could thus in principle raise additional revenues and have a significant redistributive effect. However, there could also be substantive behavioural effects that could be damaging not just to the size of the total 'cake' but also to its future growth. The effects of increased taxation on aggregate saving is, though, difficult to determine in theory (as the income and substitution effects of reducing the effective net of tax rate of return may go in opposite directions) and in practice (given the many other determinants of aggregate saving). 
95. The large literature on the effects of taxation of capital income is summarised in Attanasio and Wakefield (2010), who conclude that the behavioural response is small. On the other hand, there is an argument that, because the tax distortion of savings compounds over time, income from capital should not be taxed. This argument holds even if the behavioural effect is small, provided it is not actually zero. Banks and Diamond (2010) analyse this argument in detail and conclude that it only applies in very restrictive circumstances. They conclude that capital income should be taxed but are agnostic about the appropriate rate.

96. These uncertainties about the behavioural effects of taxing capital income suggest, particularly in a small open economy, some caution with regard to options to raise tax rates on capital income across the piece. However, there is rather more evidence that significant distortive effects can arise from treating different sources of capital income differently, e.g. effectively exempting (or even subsidising) the return on owner occupied housing tends to divert saving and investment away from other activities that may be more growth-oriented.

97. The problem is, though, how to design and implement a more rational and neutral regime. One approach with significant support in the economics literature would be to introduce some form of 'expenditure' tax in which only capital income in excess of a 'normal' rate of return would be taxed, as proposed in the recent Mirrlees review report, Tax by Design (2010). Whatever the potential advantages of such a regime on economic efficiency grounds, it would tend to make already-wealthy people even better off through taxing their capital income more lightly. For this to be socially acceptable, much more rigorous taxation of capital transfers not only on death but also inter vivos would almost certainly be needed. Giving savers some form of 'Rate of Return Allowance' would, though, permit progressive taxation of capital income in excess of this allowance. By contrast Dual Income Tax regimes - another approach to rationalising the tax treatment of capital income - have (in the forms that have been adopted to date) applied a proportional tax regime to capital income (while continuing to tax labour income under a progressive rate structure).

98. A more practicable approach, in the short term at any rate, might be to scale back tax reliefs and tax expenditures for capital income that benefit high income recipients disproportionately. Tax reliefs to encourage saving for retirement or owner occupation of dwellings were often designed primarily with people of more modest means in mind, but, if they are uncapped, can provide large tax savings to high income recipients. The arguments set out above for seeking to raise more revenues from top income recipients by raising their average tax rate without raising marginal rates apply as strongly to capital as employment income; and it is desirable therefore to evaluate the costs and benefits of these tax breaks accordingly.

\section{Capital gains}

99. This section looks first at two areas where the treatment of remuneration as gains for tax purposes (rather than ordinary income) may particularly favour the top executives, finance professionals and entrepreneurs who account for a large proportion of the increased share of top income recipients in total income (especially in countries like the US) - the tax treatment of 'carried interest' arrangements and of stock options.

100. In the former case, individuals may benefit from 'carried interest' arrangements where they may have a relatively small equity stake in a business or collective investment vehicle that they run, but, if successful, they may stand to gain rewards that are highly geared to the overall return; and which are then taxed as capital gains, and hence at a rate that is generally below their marginal income tax rate. The benefits from such arrangements (e.g. the sharpening of incentives for managers to maximise profits) would appear to accrue to the parties involved, so there is no obvious 'market failure' or externalities 
argument to justify a tax subsidy. It would seem reasonable, therefore, to treat this (relatively unusual) form of remuneration in the same way as ordinary income. Similar considerations apply where a significant part of the remuneration of top executives etc takes the form of stock options and the benefit is taxed as a capital gain rather than ordinary income. In both cases treating the remuneration as ordinary income rather than capital gains would look to be more equitable and would ensure that top income recipients pay a higher average tax rate.

101. A wider reform option that would constrain the opportunities to reduce tax liabilities by arbitraging between capital gains and ordinary income, not only with regard to employment income but also capital income, would be to align the tax rates that apply to income and gains more closely. Differences in tax rates on different types of income (e.g. interest compared with capital gains) are at the heart of many income-shifting tax planning and more aggressive avoidance opportunities. In a world where asset prices can readily be established in broad secondary markets, the case for aligning the taxation of ordinary income and gains would be strong. In reality the pros and cons are more complex and the evidence is less clear cut; unfortunately, a full assessment is outside the scope of this paper. (For a fuller discussion, see OECD, 2006.)

\section{The personal / corporate income tax boundary}

102. As earlier sections of this chapter have noted, some of the increase in the share of top income recipients can be attributed in some countries (notably the US) to the increased use of pass-through entities (particularly S-corporations and limited liability partnerships in the US) rather than the previously standard corporate form; and more business income therefore being reported as personal income in order to benefit from a lower tax rate. In some other countries the tax incentive has worked the other way and incorporation has been favoured. Other tax planning opportunities may arise in countries where the use of trusts is part of the legal framework and capital income within a trust benefits from a concessionary tax rate. Closer alignment of the rates at which business and capital income are taxed, whatever the legal form, could potentially raise more tax revenues from the well-advised, high income taxpayers who take advantage of these tax planning opportunities; and also reduce the incentives to devote time and resources to tax planning.

\section{Taxation of wealth and capital transfers}

103. In this chapter we have focused on the distribution of income, notably trends in the shares of top income recipients, rather than the distribution of wealth. It has not been possible to explore such issues as the accumulation of wealth from income, or the role of inter-generational transfers in perpetuating inequality in income. Taxation of wealth and estates/ inheritances in any case raises wider issues, such as whether concentration of wealth has harmful effects on society, e.g. through its effects on the balance of political power and influence in a country. It is also one of the most controversial areas of tax policy. For the purposes of the present paper it can simply be noted that there are good economic arguments for maintaining progressive taxation of the estates of the very rich and for reducing the extent to which tax planning can make it a 'voluntary' tax for such individuals - see for instance, Auerbach (2006). Possible approaches to reforming the taxation of wealth and wealth transfers are discussed in Boadway, Chamberlain and Emmerson (2010).

\section{Property taxes}

104. Residential property is generally taxed at lower effective rates than other categories of consumption and other forms of capital income in most OECD countries. In particular, the imputed rent from owner occupation is generally not subject to tax. The associated distortion of consumption and investment decisions are likely to harm not only economic welfare but also growth prospects (OECD, 
2010b). Reform of the taxation of residential property is thus desirable for a variety of reasons. This could in principle be part of a comprehensive reform to achieve a more neutral tax regime for saving and investment (whether on the basis of comprehensive income tax or expenditure tax à la Mirrlees). In practice a more piecemeal approach might be a more practicable option, e.g. bringing the tax base for taxes on residential property more into line with market values. Reducing the extent to which residential property is a tax shelter would increase the amount of tax paid by top income recipients. This would be a fortiori the case if it were possible to apply a progressive rate structure to its return. The political and practical obstacles to taxing the return on (owner occupied) residential property at progressive rates appear, though, to be significant, with no current country examples within the OECD area.

\section{High net worth individuals: evasion and aggressive avoidance}

105. Top income recipients often either have the means to get tax planning advice on reducing their tax liabilities, or the opportunity to 'under-declare' income (e.g. by treating consumption as a business expense, or keeping income offshore). A wide range of tax planning activities is quite lawful. In principle governments could make them less attractive or practicable by more closely aligning the tax rates that apply to different types of income (thus reducing arbitrage and sheltering opportunities) or making such arbitrage harder by putting regulatory obstacles in the way. Other tax avoidance schemes may be more artificial and contrived, with little underlying commercial substance. OECD countries have developed a range of countermeasures including changes in the way tax legislation is drafted, the use of targeted or general anti-avoidance rules, requirements for the developers of tax avoidance schemes to disclose their existence to the tax authorities, more systematic use of third party information, the threat of retrospective legislation and the development of specialised tax units to handle High Net Worth Individuals.

106. Economic analysis of tax evasion has tended to based on a model where taxpayers behave rationally and their utility depends only on income (so there is no moral dimension to their behaviour). In a simple model on these lines tax evasion is a function of the tax rate (and hence the potential amount of tax saved, if successful), the risk of detection and the penalty to be paid if detected. Such a model tends to over-predict the amount of evasion. It also suggests a trade-off between the penalty rate and deploying resources to increase the risk of detection that is unlikely to be socially acceptable, i.e. that cutting administrative resources can be offset by a high penalty rate when evasion is detected. There is likely to be limits to the level of penalties that is acceptable, as very high penalties for the handful of evaders who get caught would be perceived as unfair if many people are able to evade tax scot free.

107. These considerations point to putting the focus on seeking to change the moral climate so that tax fraud becomes more socially unacceptable, plus more effective deployment of administrative resources to increase the (actual and perceived) rates of detection of evasion. In this regard, collection of information from third parties to enable taxpayers' declarations to be verified is invaluable, as is securing the active cooperation of financial institutions in countering evasion. The OECD's work on the exchange of information for tax purposes is particularly important in reducing the chances of successful evasion by keeping income and wealth offshore.

\section{Concluding remarks}

108. The rise in the share of top income recipients in total income is a sign that their 'ability to pay' tax may have increased. This section has therefore examined a number of options for increasing the amount of tax that top income recipients pay and provided an overview assessment of their pros and cons.

109. Economic analyses based on the effects of past cuts in top marginal tax rates suggest that taxable income elasticities are quite high for top earners. While this may be attributable in part to tax planning 
effects, changes in top tax rates do appear to have significant effects on real behaviour. Trade-offs between equity and economic efficiency must therefore be taken seriously.

110. Tax reforms that enable an increase in the average rate of tax paid by top income recipients, without raising their marginal rates, may thus be attractive. Possibilities include:

a) Aligning the taxation of owner-occupied residential property more closely with actual market values and returns; and perhaps also applying a progressive rate structure to those returns.

b) Abolishing or scaling back a wide range of tax expenditures which tend to benefit high income recipients disproportionately.

111. Such reforms are very much in line with those recommended by the OECD in its tax policy brief 'Tax Policy Reform and Fiscal Consolidation' and associated Tax Policy Studies (OECD, 2010a and 2010b). Other tax policy options that might be considered include taxing all remuneration as ordinary income including fringe benefits, carried interest arrangements and stock options; and perhaps closer alignment of the tax treatment of capital gains and ordinary income. On the administrative side, policies to improve compliance are likely to bear particularly on top income recipients.

112. While measures focused on raising average effective tax rates on top incomes without raising top marginal rates should be less harmful to economic welfare and the potential for economic growth, there may be limits to such a strategy as top income recipients tend to be more geographically mobile than most citizens. They are thus more likely to change their country of residence in response to higher tax rates on income and wealth. They may also have more opportunity to keep income offshore and not declare it to the tax authorities. The OECD work in developing exchange of information for tax purposes is addressing this issue. 


\section{References}

Aaberge, R. and A.B. Atkinson (2010), 'Top incomes in Norway', in Atkinson and Piketty (2010).

Alvaredo, F. (2010), 'Top incomes and earnings in Portugal, 1936-2005', in Atkinson and Piketty (2010).

Alvaredo, F. and E. Pisano (2010), 'Top incomes in Italy 1974-2004', in Atkinson and Piketty (2010).

Alvaredo, F. and E. Saez (2010), 'Income and wealth concentration in Spain in a historical and fiscal perspective', in Atkinson and Piketty (2010).

Atkinson, A.B. (2007a), 'Measuring top incomes: methodological issues', in Atkinson and Picketty (2007).

Atkinson, A.B. (2007b), 'The distribution of top incomes in the United Kingdom 1908-2000', in Atkinson and Piketty (2007).

Atkinson, A.B. (2008), The Changing Distribution of Earnings in OECD Countries. Oxford: Oxford University Press

Atkinson, A. B. and A. Brandolini (2001), 'Promise and Pitfalls in the Use of "Secondary" Data-Sets: Income Inequality in OECD Countries', Journal of Economic Literature, vol. 34, pp. 771-799.

Atkinson, A.B. and A. Leigh (2007a), 'The distribution of top incomes in Australia', in Atkinson and Picketty (2007).

Atkinson, A.B. and A. Leigh (2007b), 'The distribution of top incomes in New Zealand', in Atkinson and Piketty (2007).

Atkinson, A.B. and A. Leigh (2010), 'The distribution of top incomes in five Anglo-Saxon countries over the twentieth century', IZA Discussion Papers, No. 4937.

Atkinson, A.B. and T. Piketty (2007), Top Incomes over the Twentieth Century: A Contrast between Continental European and English-Speaking Countries. Oxford: Oxford University Press.

Atkinson, A.B. and T. Piketty (2010), Top Incomes over the Twentieth Century: A Global Perspective. Oxford: Oxford University Press.

Atkinson, A.B., T. Piketty and E. Saez (2009), 'Top incomes in the long run of history', NBER Working Paper, No. 15408. Data appendix available online at: http://elsa.berkeley.edu/ saez/

Attanasio, O. and M. Wakefield (2010), 'The effects on consumption and savings of taxing asset returns', in Dimensions of Tax Design: The Mirrlees Review, Oxford: Oxford University Press for the Institute for Fiscal Studies.

Auerbach, A. (2006), 'The future of capital income taxation', Fiscal Studies, vol. 27, pp. 399-420. 
Auten, G., and G. Gee (2009), "Income mobility in the United States: New evidence from tax return data", National Tax Journal Vol. LX11, No2, June 2009.

Bach, S., G. Corneo and V. Steiner (2007), 'From Bottom to Top: The Entire Distribution of Market Income in Germany, 1992 - 2001', DIW Berlin Discussion Papers, No. 683.

Bakija, J., A. Cole and B. Heim (2010) 'Jobs and Income Growth of Top Earners and the Causes of Changing Income Inequality: Evidence from U.S. Tax Return Data' Department of Economics Working Papers 2010-24, Department of Economics, Williams College, revised Nov 2010.

Banks, J. and P. Diamond (2010), 'The Base for Direct Taxation', in Dimensions of Tax Design: The Mirrlees Review, Oxford: Oxford University Press for the Institute for Fiscal Studies.

Boadway, R., E. Chamberlain and C. Emmerson (2010), 'Taxation of wealth and wealth transfers', in Dimensions of Tax Design: The Mirrlees Review, Oxford: Oxford University Press for the Institute for Fiscal Studies.

Bradbury, Katherine and Katz Jane (2002), "Are lifetime incomes growing more unequal? Looking at new evidence on family income mobility", Regional Review: Federal Reserve Bank of Boston, Vol 12., No4.

Brewer, M., E. Saez and A. Shephard (2010), 'Means-testing and tax rates on earnings', in Dimensions of Tax Design: The Mirrlees Review, Oxford: Oxford University Press for the Institute for Fiscal Studies.

Chetty, R. (2009), 'Is the taxable income elasticity sufficient to calculate deadweight loss? The implications of evasion and avoidance', American Economic Journal: Economic Policy, vol. 1, pp. $31-52$.

Dell, F. (2007), 'Top incomes in Germany throughout the twentieth century: 1891-1998', in Atkinson and Piketty (2007).

Department of Finance Canada (2010), 'The Response of Individuals to Changes in Marginal Income Tax Rates', in Tax Expenditures and Evaluations 2010.

Department of the Treasury (2007), Background paper for Conference on Business Taxation and Global Competitiveness

Edlund, L. and W. Kopczuk (2009), “Women, Wealth and Mobility”, American Economic Review, (99), pp. 146-78

Feldstein, M. (1995), ' The effects of marginal tax rates on taxable income: a panel study of the 1986 Tax Reform Act', Journal of Political Economy, vol. 108, pp. 551-572.

Gruber, J. And E. Saez (2002), 'The elasticity of taxable income: evidence and implications', Journal of Public Economics, vol. 84, pp. 1-32.

Holmlund, B. and M. Söderstrom (2007), 'Estimating income responses to tax changes: a dynamic panel data approach', IZA Discussion Papers, No. 3088.

HMRC Statistics, Table 2.4 Shares of total income and income tax by percentile group 
Jäntti, M., M. Riihelä, R. Sullström and M. Tuomala (2010), 'Trends in top income shares in Finland', in Atkinson and Piketty (2010).

Kopczuk, W. and E. Saez (2004), 'Top wealth shares in the United States, 1916-2000: Evidence from Estate Tax Returns', National Tax Journal, 57(2) pp. 445-488

Kuznets, S. (1953), Shares of Upper Income Groups in Income and Savings. New York: National Bureau of Economic Research.

Leigh, A. (2007), 'How closely do top income shares track other measures of inequality?', Economic Journal, vol. 117, No. 524.

Lemieux, T., W. B. MacLeod and D. Parent (2007), 'Performance pay and wage inequality' NBER Working Paper, No. 13128.

Meghir, C. and D. Phillips (2010), 'Labour supply and taxes', in 'Dimensions of Tax Design' volume of the Report of a Commission on Reforming the Tax System for the $21^{\text {st }}$ Century, chaired by Sir James Mirrlees, available at: www.ifs.org.uk/mirrleesreview

Mirrlees, J. and others (2010), 'Tax by Design', available at www.ifs.org.uk/mirrleesreview

Moriguchi, C. and E. Saez (2010), 'The evolution of income concentration in Japan, 1886-2005: evidence from income tax statistics', in Atkinson and Piketty (2010).

Mudry, K. and J. Bryan (2009), 'Individual income tax rates and shares, 2006', IRS Statistics of Income Bulletin, (Winter), pp. 5-45

Nolan, B. (2007), 'Long-term trends in top income shares in Ireland', in Atkinson, A.B. and T. Piketty (2007).

OECD (2006), ‘Taxation of capital gains of Individuals', Tax Policy Study No. 16

OECD (2008), Growing Unequal? Income Distribution and Poverty in OECD Countries. Paris: OECD.

OECD (2010a), ‘Choosing a Broad Base - Low Rate to Taxation', Tax Policy Study No. 19

OECD (2010b), ‘Tax Policy Reform and Economic Growth', Tax Policy Study No. 20

Piketty, T. (2001), Les Hauts Revenue en France au 20ème Siècle. Paris: Grasset.

Piketty, T. (2003), 'Income inequality in France, 1901-1988', Journal of Political Economy, vol. 111, pp. 1004-42.

Piketty, T. (2007), 'Income, wage and wealth inequality in France', in Atkinson and Piketty (2007).

Piketty, T. and E. Saez (2007), 'Income and wage inequality in the United States, 1913-2002', in Atkinson, A.B. and T. Piketty (2007).

Roine, J. and D. Waldenström (2010), 'Top incomes in Sweden over the twentieth century', in Atkinson and Picketty (2010). 
Roine, J. and D. Waldenström (2008), 'The evolution of top incomes on an egalitarian society: Sweden, 1903-2004', Journal of Public Economics, vol. 92, pp. 266-387.

Saez, E., J. Slemrod and S. Giertz (2010), 'The elasticity of taxable income with respect to marginal tax rates: a critical review', Journal of Economic Literature, forthcoming. Older version: NBER Working Paper No. 15012, May 2009.

Saez, E. and M. Veall (2005), 'The evolution of high incomes in northern America: Lessons from Canadian evidence', American Economic $\backslash$ Review, vol. 95, pp. 831-849.

Saez, E. and M. Veall (2007), 'The evolution of high incomes in Canada, 1920-2000', in Atkinson, A.B. and T. Picketty (2007).

Salverda, W. and A.B. Atkinson (2007), 'Top incomes in the Netherlands over the twentieth century' in Atkinson, A.B. and T. Picketty (2007).

Slemrod, J (2007), 'Cheating Ourselves: The Economics of Tax Evasion', Journal of Economic perspectives - Volume 21, Number 1 


\section{Annex 1 \\ CHARACTERISTICS AND LIMITATIONS OF INCOME DATA FROM TAX RETURNS}

Section 2 above set out the considerable strengths of tax return data as a source of information for analysing trends in top incomes. It also noted a number of limitations to the comparability of such data over time and across countries. This annex describes in more detail some of the points that users of data from tax returns need to bear in mind in analysing and interpreting the data.

\section{Nature and characteristics of data from income tax returns}

Given that the income data are derived from tax returns, there is a risk that they could be significantly affected by under-declaration of income. Moreover, the extent of such under-reporting can vary across taxpayers. For instance, detailed audit of tax returns might suggest that the overall 'tax gap' (between actual tax paid and what should have been paid if income had been correctly stated) might be of the order of 10 per cent of personal tax income revenues, but the "gap" may be small for employees whose employer deducts tax at source and provides income information directly to the tax authorities, but over 50 per cent for farmers and the self-employed (where little third party information may be available for verification purposes) - see, for instance, Slemrod (2007). The extent of under-declaration of incomes may also vary across countries, reflecting for instance cultural mores with regard to tax compliance and the rigour with which the tax authorities administer the tax regime.

The tax authorities generally only collect information on income that is potentially taxable. This can result in significant exclusions (e.g. the imputed rent from owner occupation is not now taxed in most OECD countries) and breaks in time series (e.g. at the point in time when such imputed rent ceased to be taxed). Differences in tax regime can thus lead to differences in the concept of 'income' used in different countries.

The tax unit varies between countries. In some countries it is the individual, while in others couples are required to file jointly. Thus the following countries operate a tax regime based on individual taxation: Australia, Canada, Italy, Japan, New Zealand (from 1953), Spain and the UK (from 1990). The following have joint filing: France, Germany, Ireland, Netherlands, Portugal and Switzerland. And some countries allow a degree of discretion to the taxpayer, including Finland, Norway and Sweden. A number of countries have changed the tax unit over time, generally in the direction of moving from joint to individual taxation.

The geographical extent of a country can change over time, e.g. Germany.

Estimating the incomes of the 'non-filing' population may be only approximate, e.g. because of differences in the income concepts used for income tax purposes and those used in estimating other incomes.

Capital gains are likely to be more important for top income groups than the rest of the population, but data on gains may not be collected with the same regularity and on the same basis as for ordinary income. Moreover, data are for realised gains and losses (rather than accruals) and realisations tend to vary with asset price cycles. Realised gains can also be quite 'lumpy'. An individual may have a large amount of gains one year when (s)he sells a business that has been built-up over a period of years, but then much 
smaller gains in subsequent years. As a result the composition of, say, the top percentile group may vary more from year to year when shares are based on income including gains rather than on income excluding gains. On the other hand, capital gains are often taxed more favourably than income. This may enable the rich and well advised to arrange for a substantial part of their income to take the form of asset appreciation. Ignoring gains thus may mean missing significant developments at the top of the income distribution.

Other tax planning and tax avoidance activities can also affect the amount of income declared on tax returns. For instance, it may be possible not only to defer income taxation by sheltering wealth in trusts or in a closely-held company, but also to pay a lower rate of taxation. For instance, New Zealand has found that differences between the top marginal income tax rate and the effective tax rate of income from trusts have had a significant impact on the use of trusts. Tax planning strategies for high earning employees can also included 'salary sacrifice' in order to take more of their remuneration in the form of employerprovided fringe benefits that are taxed at a lower rate (if at all).

Changes in tax rates and tax reliefs can have a significant impact on the amount of income and the form of income declared to the tax authorities. This may reflect not only changes in tax planning strategies or in the amounts of evasion, but also changes in 'real' behaviour such as increases in labour supply and entrepreneurial effort. These factors are discussed further in section 4 of the chapter (on explaining trends in top incomes).

\section{The concept of income}

The data collected are generally for incomes before tax. However, the precise definition of gross income varies from country to country; and may well differ substantially from economic definitions of comprehensive income such as Haig-Simons (i.e. consumption plus change in net wealth).

Broad income measures can be obtained by adding back deductible and exempt items to taxable income. For example, the United States has a concept of 'cash income' that includes realised capital gains (net of capital losses) and such tax exempt items as bond interest, social security benefits and non-taxable distributions from pensions and retirement savings. (See also the further discussion of the concepts of income used in the US below.)

Even where capital gains are included in measures of 'broad' income, the measure differs from a comprehensive measure of income as they are recorded not on an accruals but on a realisations basis; and may not be recorded at all where a country has no tax on capital gains or it is assessed separately. Other significant differences from comprehensive income are the exclusion of the imputed rent on owner occupied housing and the build up of pension entitlements and other savings in pension funds, trusts and closely-held companies. Fringe benefits such as employer provided health insurance may also be excluded.

While the items mentioned in the previous paragraph imply that broad income falls short of comprehensive income, inflation can lead to overstatement (and other distortions) of measured income in relation to a comprehensive Haig-Simons concept, notably through the effects on nominal interest rates. In the case of savers, inflation is likely to boost their nominal interest receipts and this will be reflected in higher gross income. But this overstates their real income. (Strictly there should also be adjustments for the effects of inflation on interest paid on borrowing, but the 'broad income' measure does not allow for interest paid, as a comprehensive income measure should in principle do.')

\footnotetext{
$9 \quad$ Most countries measure income as including interest received but do not deduct interest paid. Denmark
} appears to be an exception. 
Differences between measured and a Haig-Simons measures of comprehensive income are likely to be more significant for top income recipients because they tend to have greater wealth and hence also more capital income and gains (that are more susceptible to measurement difficulties than, say, wage income). These differences could thus have a material effect on the share of total income going to top income recipients and its evolution over time. This is especially true in periods in which tax rates and/ or the tax base change, as these changes can alter the incentives to hold wealth in one form rather than another, and result in a switch between assets whose returns are included in the 'broad income' measure and assets (such as owner occupied housing) whose returns are excluded.

It is also worth noting that since the data are based on tax returns for a particular year, they do not represent 'permanent income' in the sense used by economists to separate out more short-term or transitory movements in income.

\section{Comparing different income measures}

Figure 1 shows the evolution of the share of the top $1 \%$ of tax units (i.e. individuals and couples) in the United States since 1987, using three different income measures. ${ }^{10}$ The lowest line represents taxable income excluding capital gains ('broad income'), the highest line represents taxable income including realised capital gains and the middle line represents cash income which also adds in some non-taxable income (and thus is in principle wider than 'broad income').

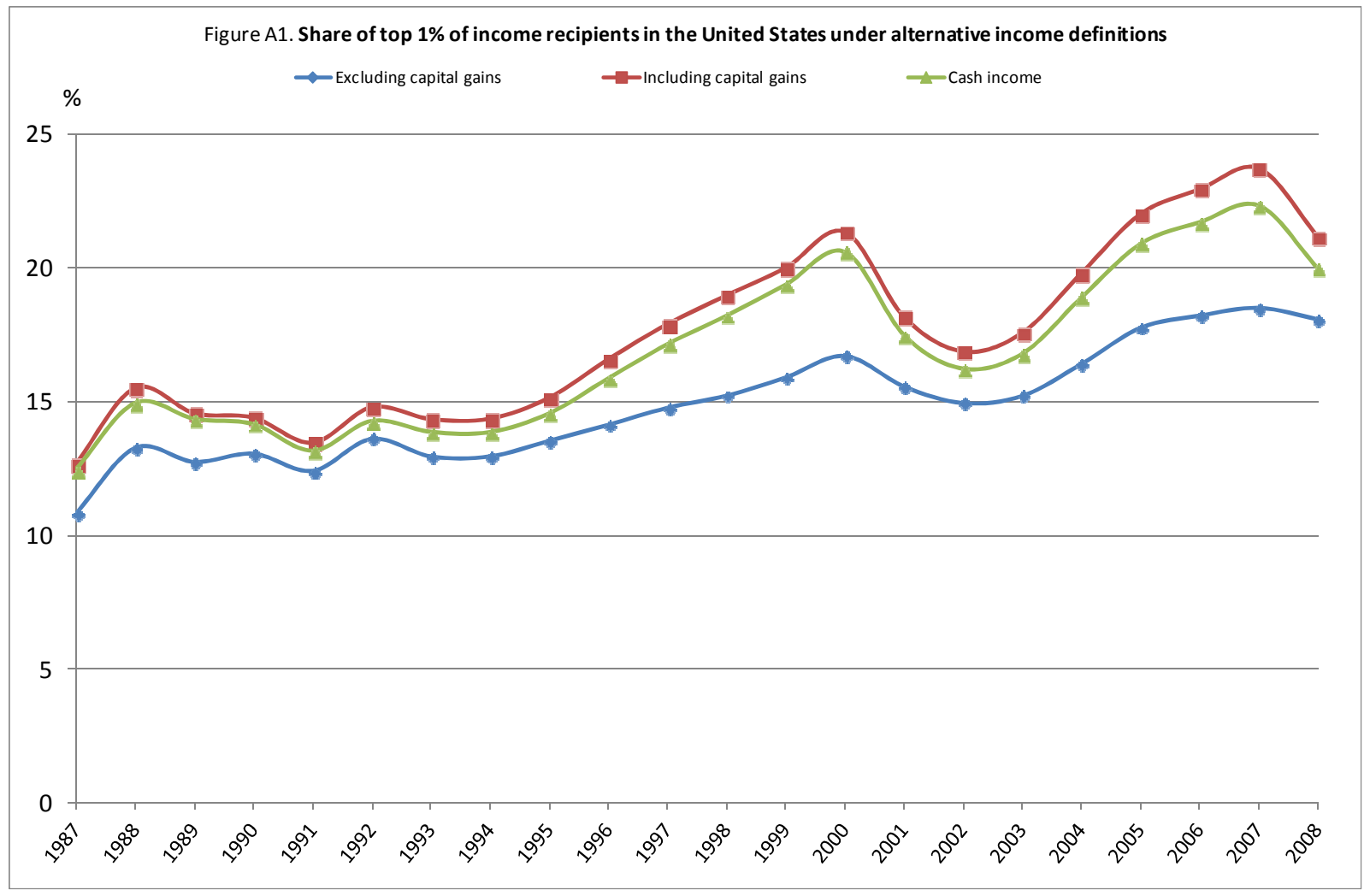

10 Note that the different measures refer to slightly different groups of tax units because each measure is obtained from considering the top $1 \%$ according to the corresponding income measure. 
In order to interpret the graph correctly, it is important to note that widening the income definition increases the average incomes of people outside the top group as well as people within it. Thus, the difference between the lines for income with and without realised capital gains reflects the difference in the shares of capital gains in the income of the top group and the population as a whole. In other words, realised capital gains are a more important component of the income of those on high earnings. This point also explains why the wider cash income measure is lower than the measure including capital gains: many of the additions to income made to obtain the cash income measure, particularly social security benefits, accrue more to those outside the top income group.

\section{Capital gains}

The comparison between the income measures with and without capital gains shows how important capital gains can be, particularly with regard to the evolution of income shares over time, with realised capital gains increasing particularly strongly in response to the economic cycle, notably the peaks that occurred in the years 2000 and 2007. As many countries tax capital gains at lower rates than other capital income, or not at all, tax planning through investments in assets that yield relatively large capital gains can be attractive.

The extent of the relative tax privilege given to capital gains and the scope to exploit it varies between countries and is one of the factors limiting the international comparability of data on top income shares. This cannot be overcome either by using measures that exclude gains (as gains may be more important in some countries than others) or measures that include gains (as there are no data on gains for many countries - not just those that do not tax them).

In addition, as Figure 1 illustrates, capital gains realisations tend to be concentrated at the peaks of economic cycles. As these realisations can be very large in comparison to other income sources (as when a business in sold), this can move people temporarily into a top income group, thus overstating the real mobility into and out of top income groups. Also in the United States, there have been surges in capital gains realisations immediately preceding expected increases in capital gains taxes, particularly as a result of the 1986 tax reforms (Saez, Slemrod and Giertz, 2010). These effects produce an imperfect picture of the pattern of accrued capital gains.

\section{Tax planning}

Another form of tax planning is to adopt the business form with the most favourable tax treatment. Once again, the 1986 tax reforms in the United States provide an example: these reforms reduced the top rate of personal income tax relative to the combined burden of the corporate income tax and personal tax on dividends/ gains; and this resulted in a shift of income from the corporate tax base to the personal tax base (Saez, Slemrod and Giertz, 2010). This produced an increase in reported personal incomes without any change in true underlying income, and so distorted the personal taxable income data.

\section{The tax unit}

Turning to the issue of the tax unit, married couples are regarded as a single tax unit in some countries, such as France (where the tax unit also includes children) and the United States. Atkinson (2007a) points out that the effect of moving from joint taxation of couples to individual taxation depends on the joint distribution of incomes of the two partners: if all rich people are single or have partners with zero income, the share of the top X\% will increase; but if rich people all have partners with the same income, the share is reduced. In this connection, it is interesting that Atkinson (2007b) shows that the shift from joint to separate taxation in the United Kingdom led to an increase in top income shares, but this does not imply that the same will be true in other countries. 
Annex 2

TOP INCOME SHARES: GRAPHICAL PRESENTATION

Figures 1-9: Shares of top $10 \%, 1 \%$ and $0.1 \%, 1970-2009$, comparative charts

Figures 10-25: Shares of fractile groups by country, 1970- latest available year

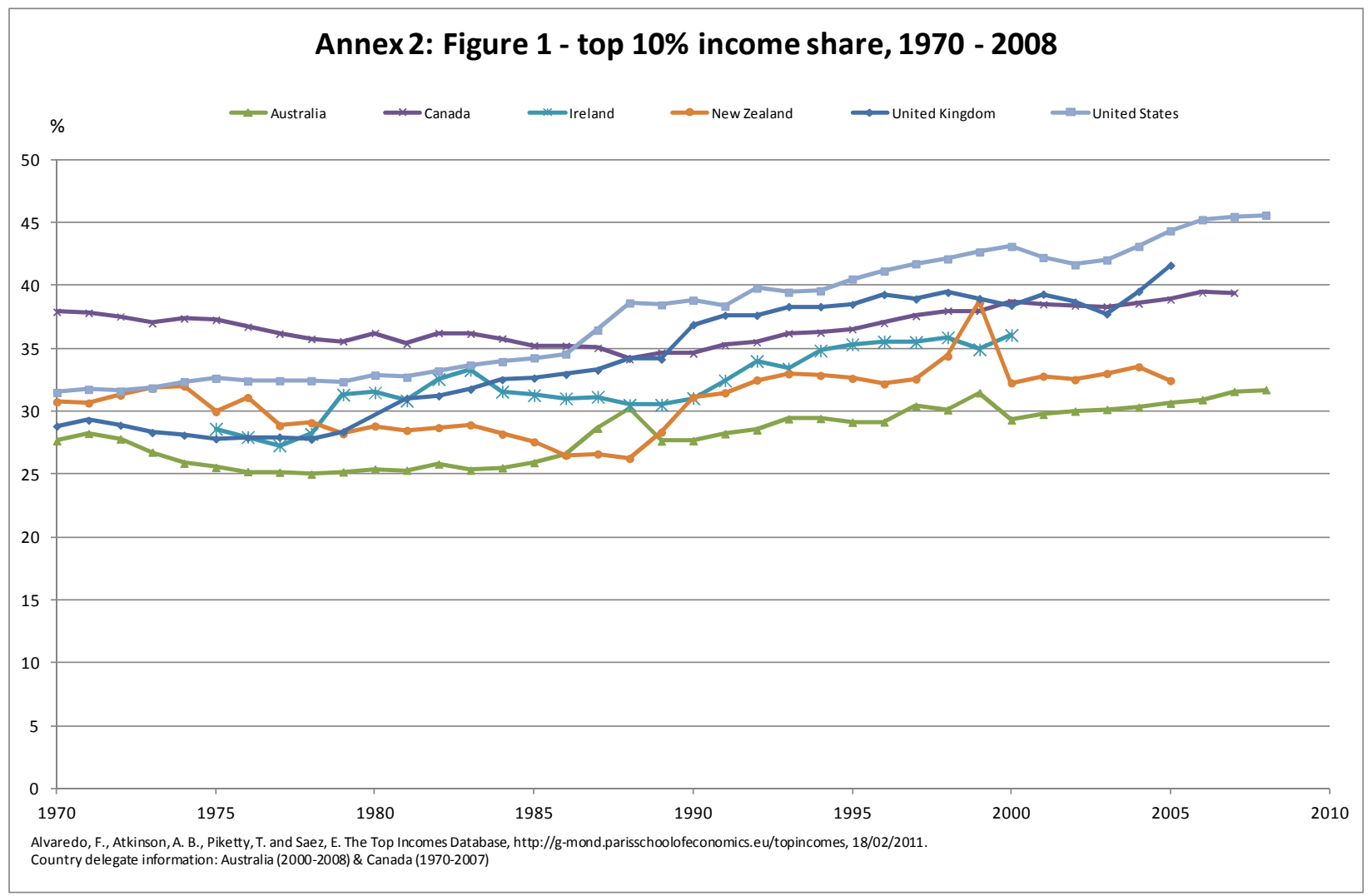



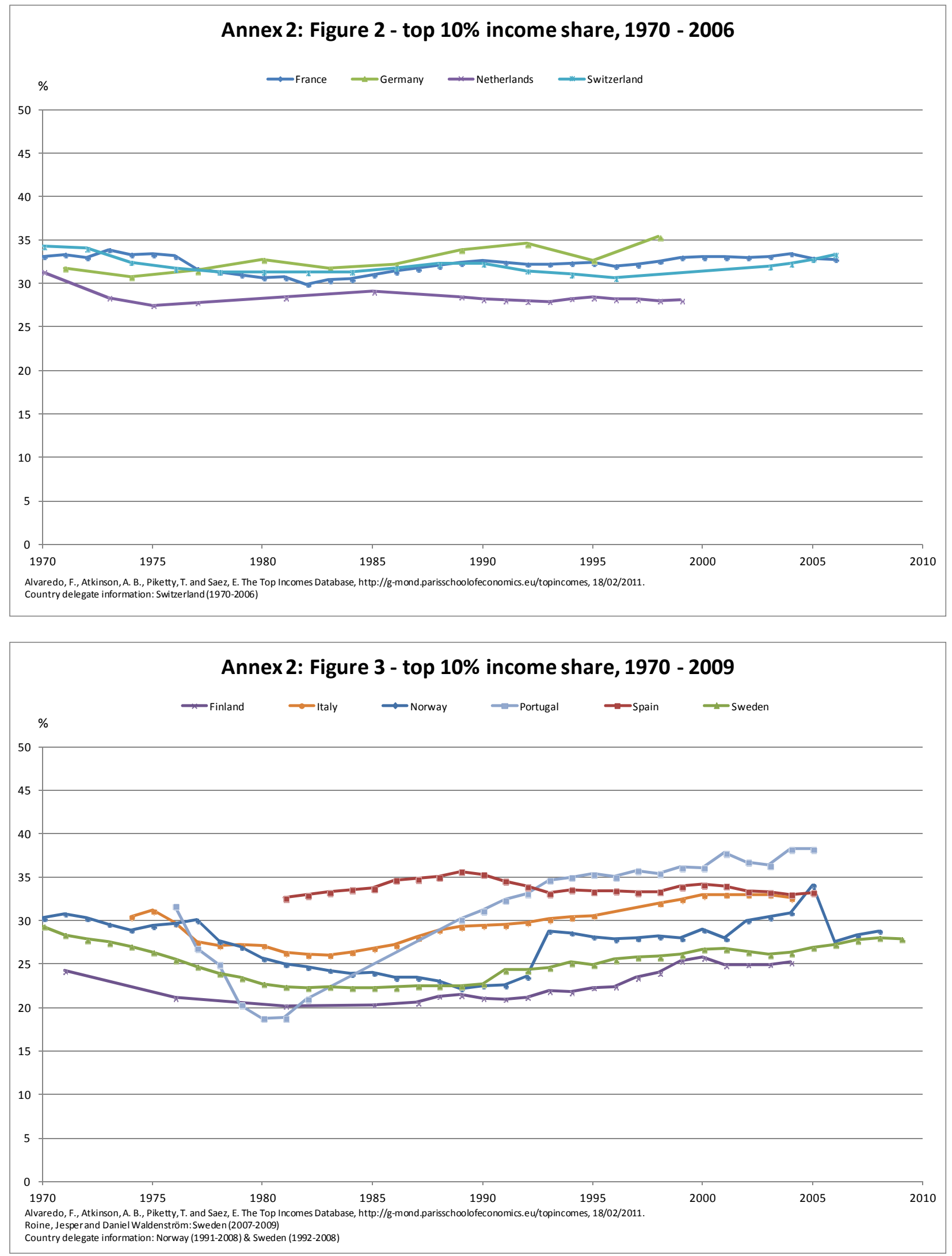

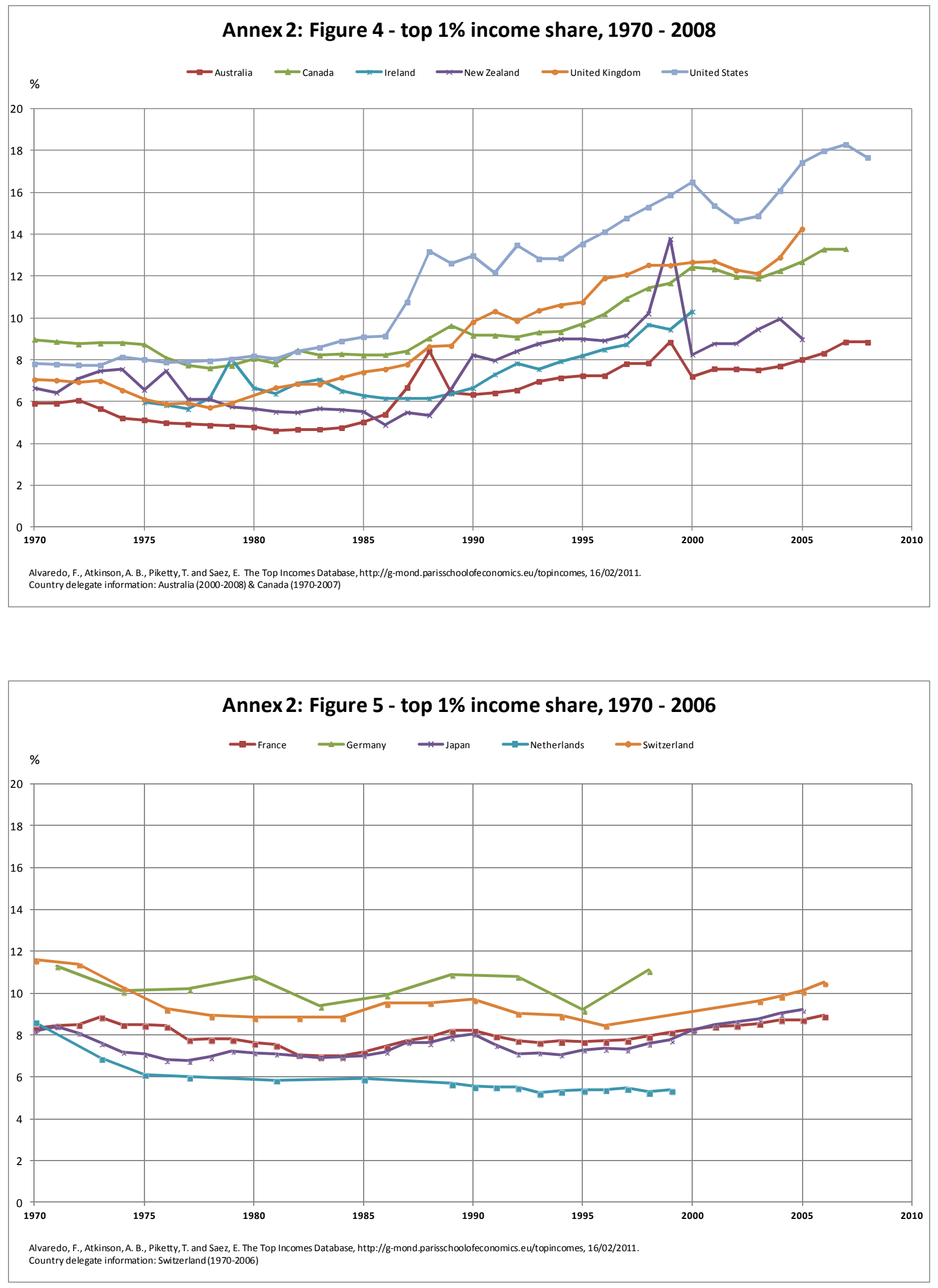

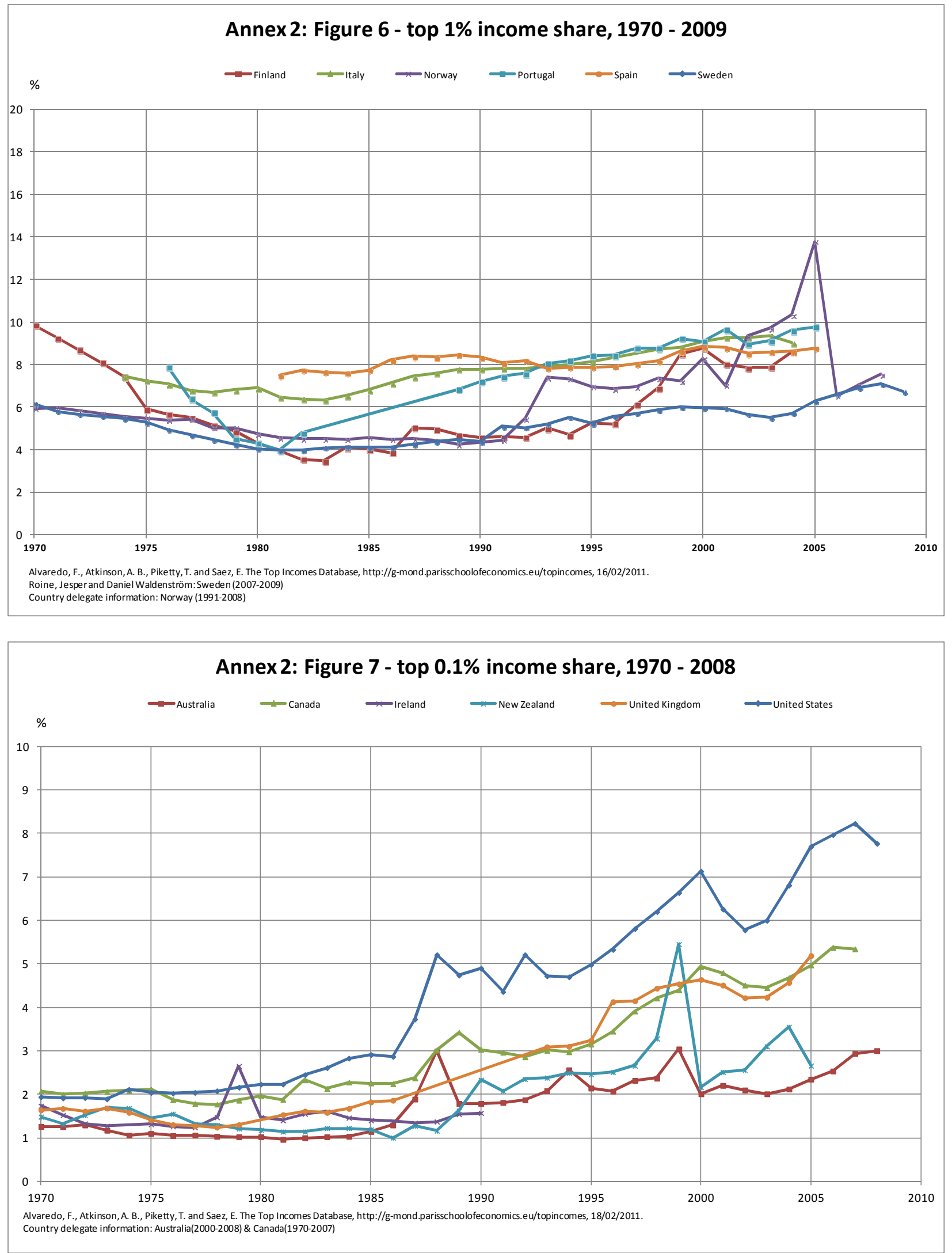

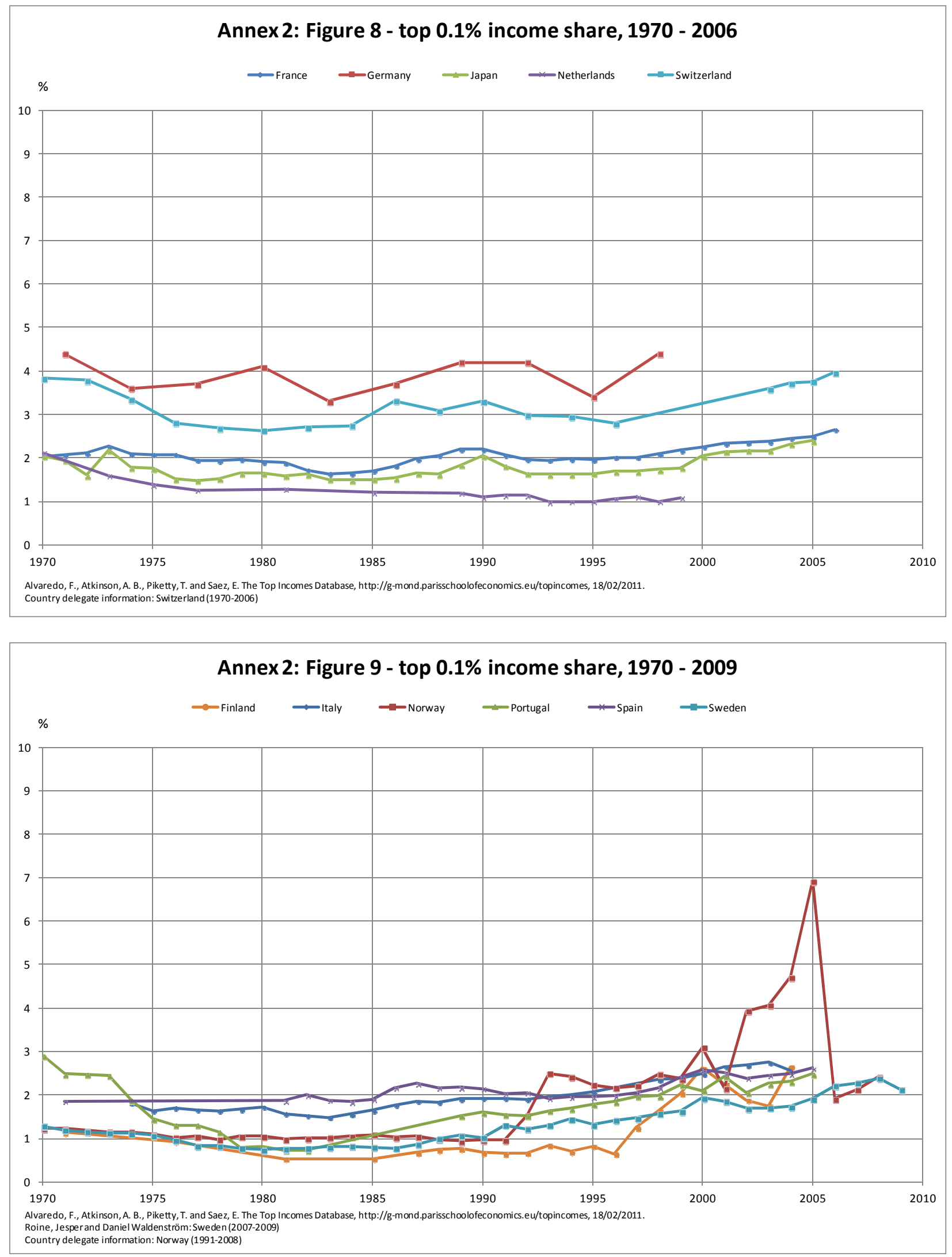

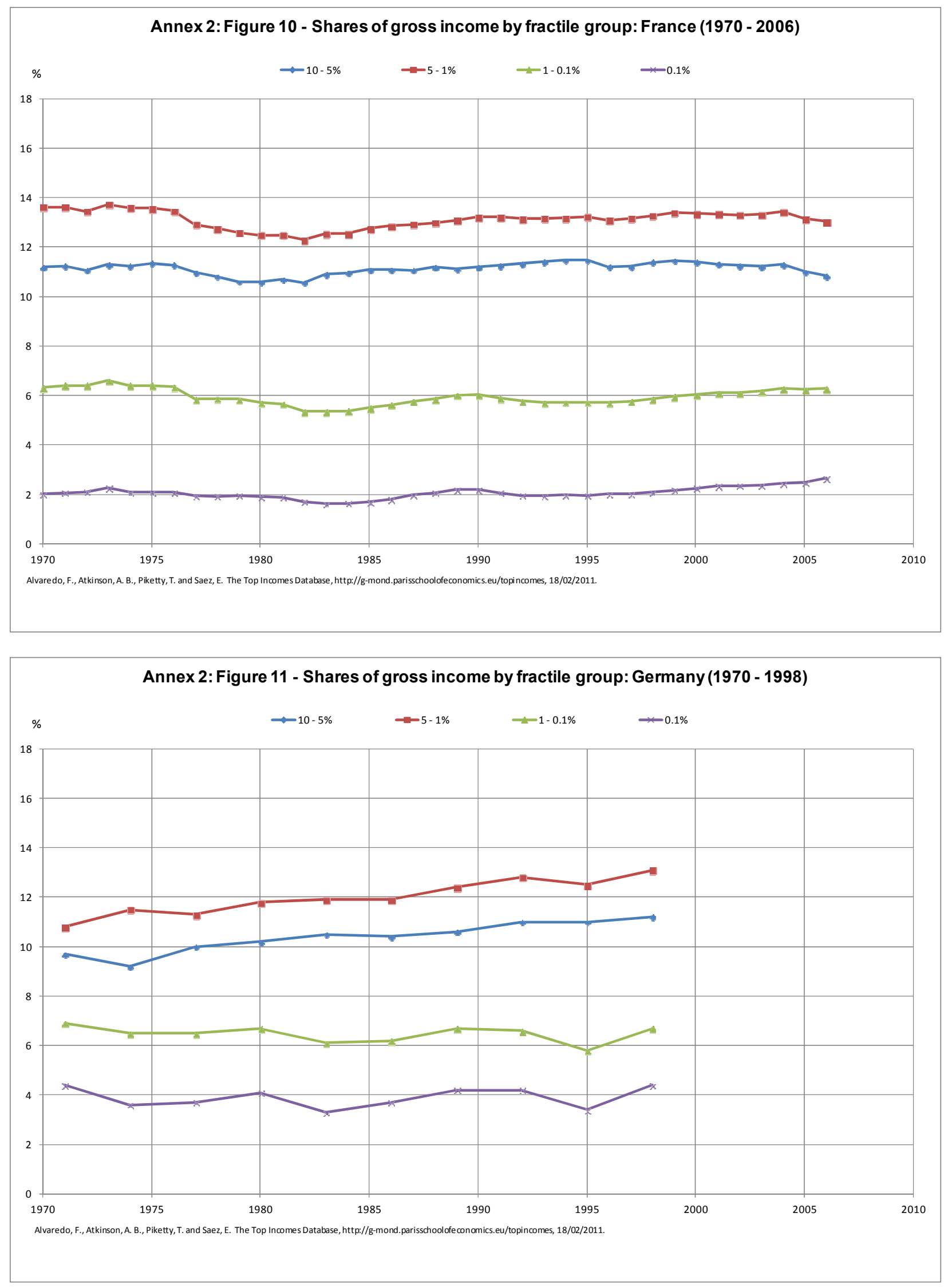

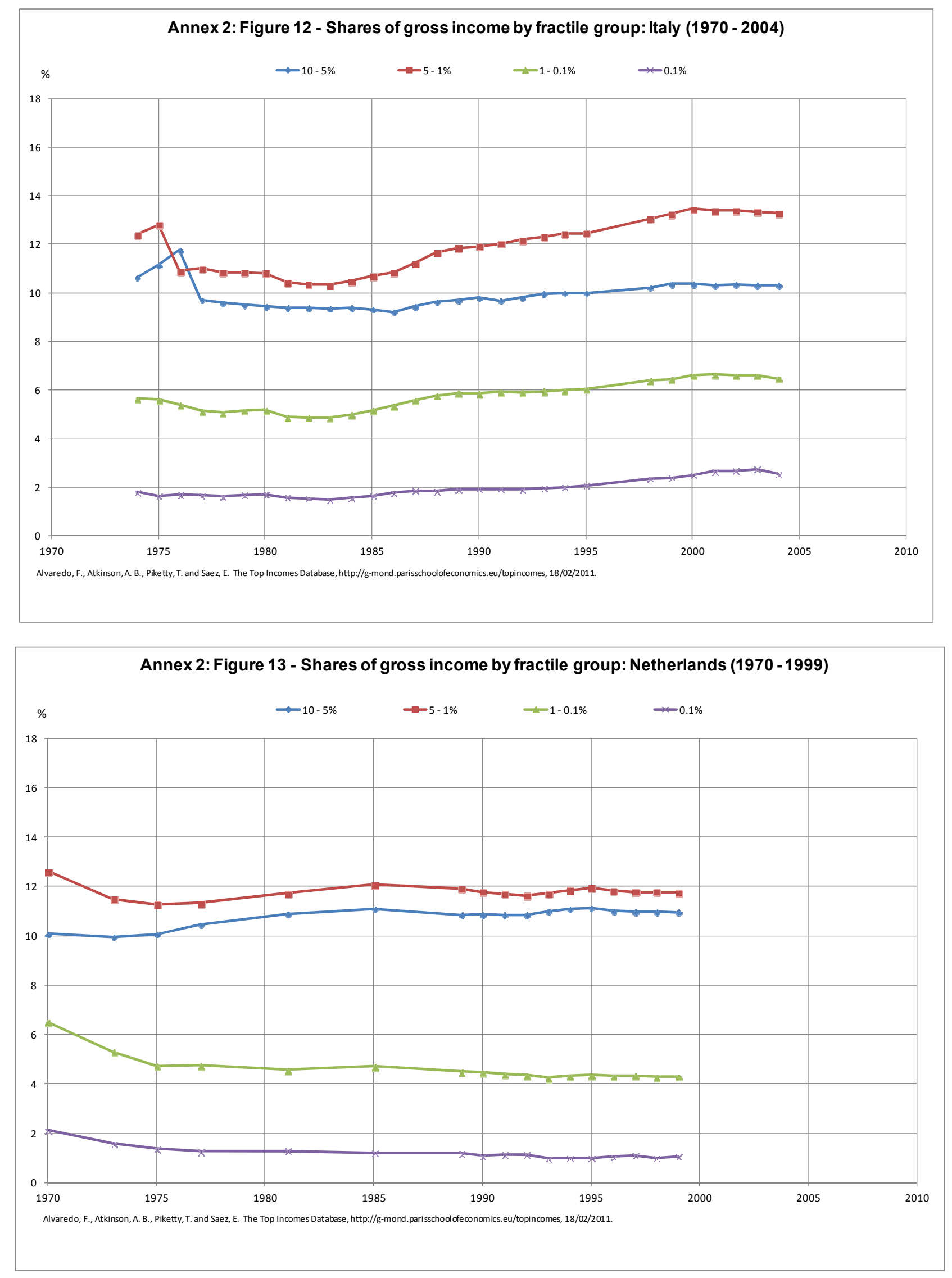


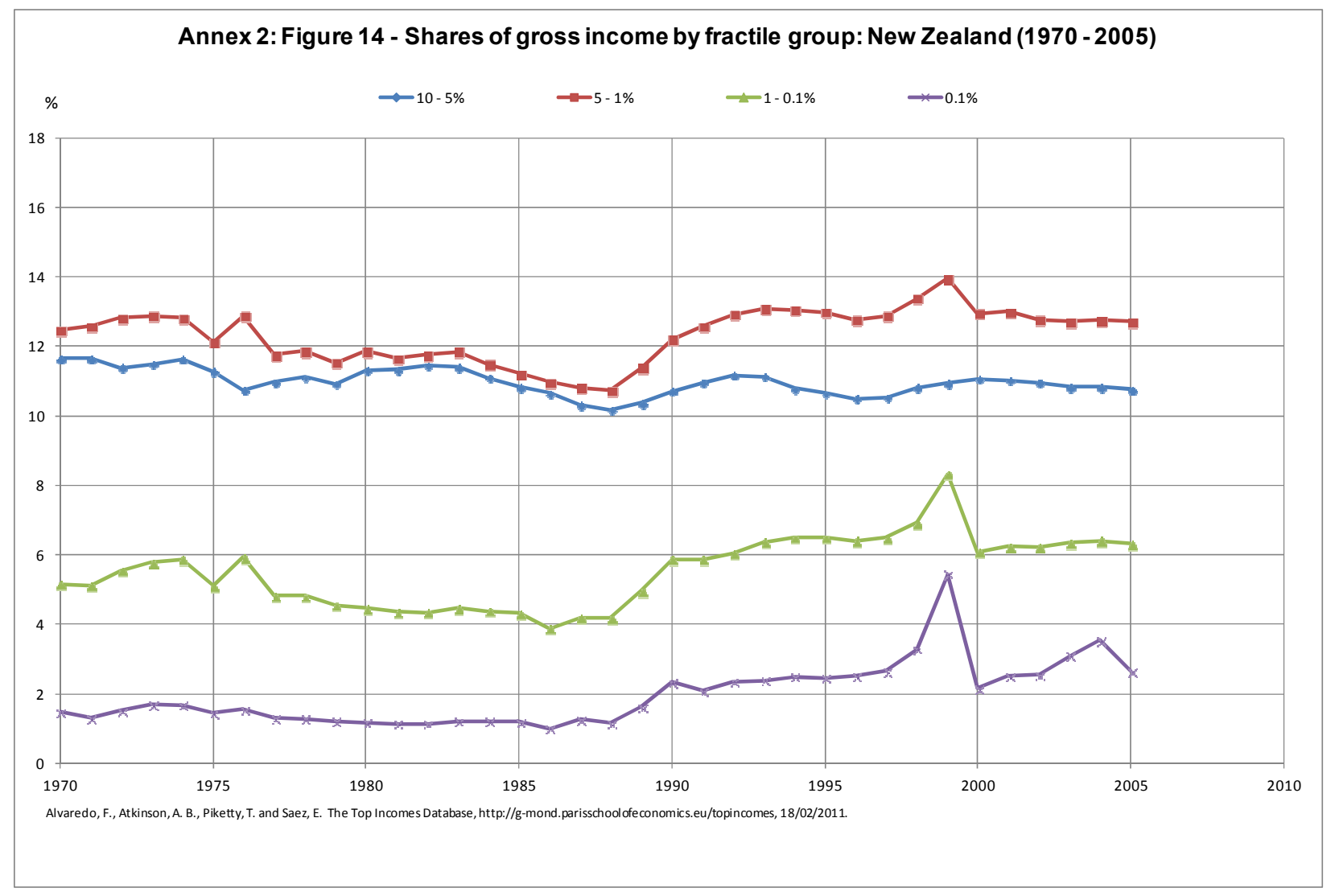

Annex 2: Figure 15 - Shares of gross income by fractile group: Portugal (1970 - 2005)

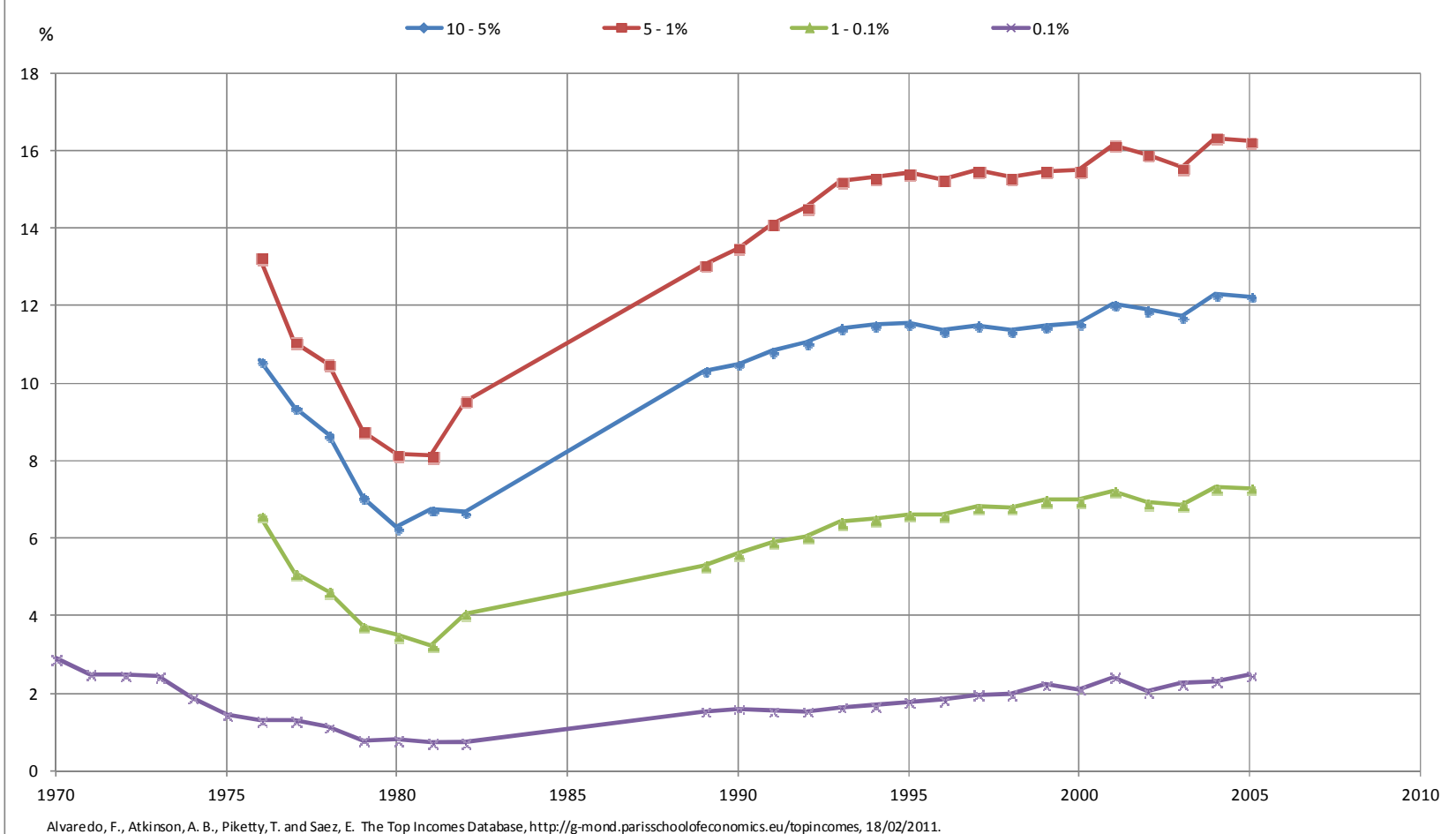



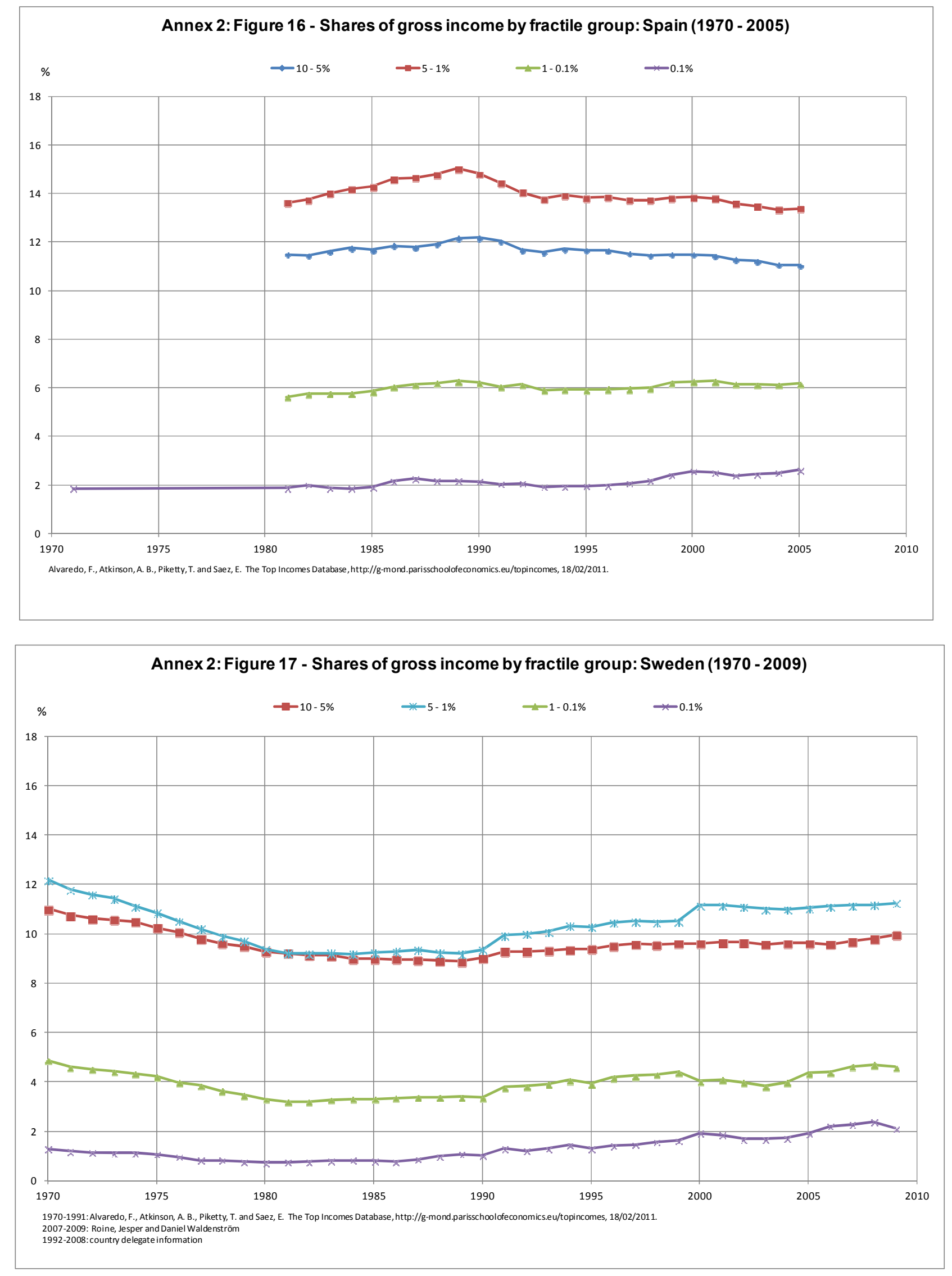

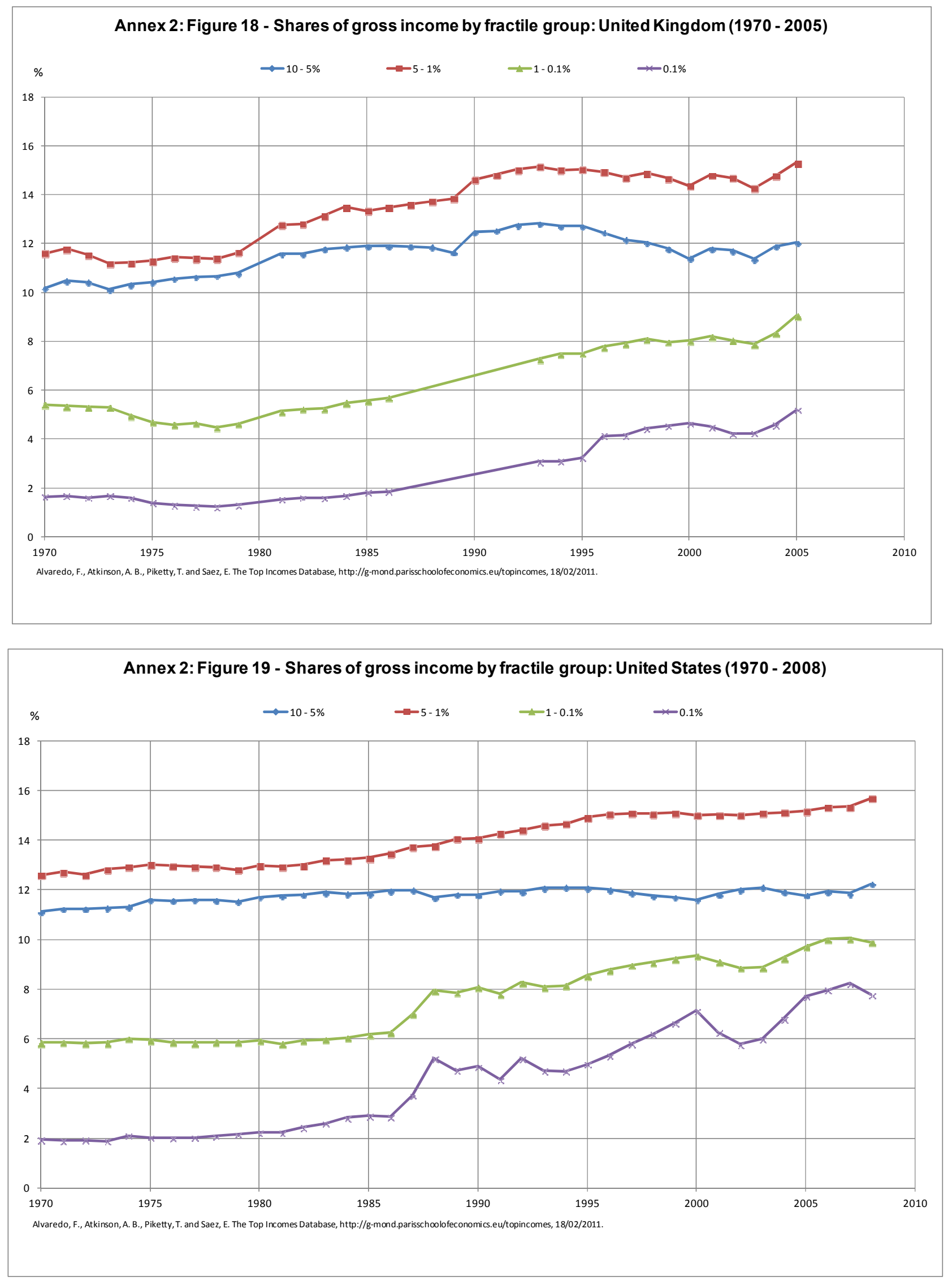

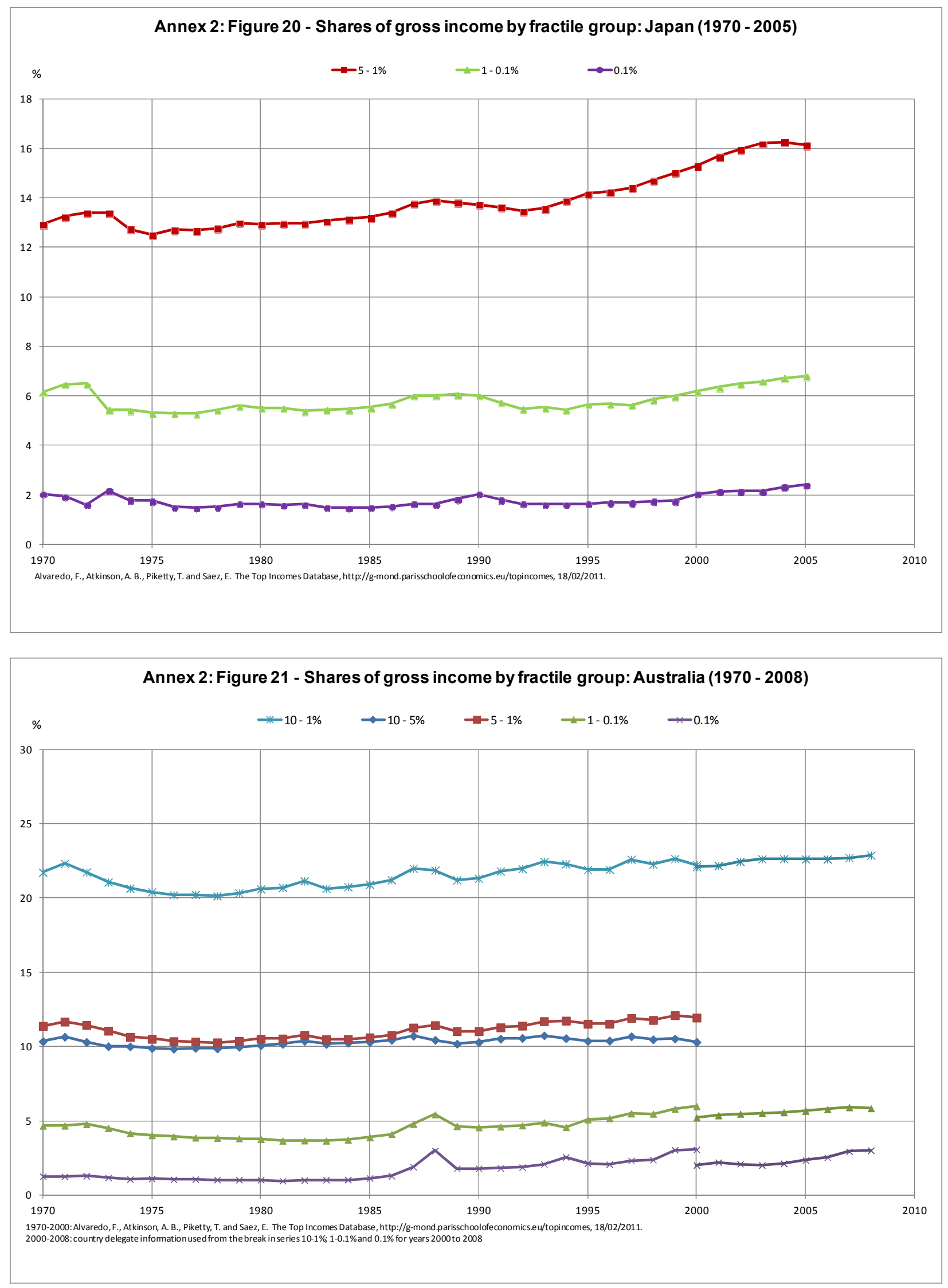


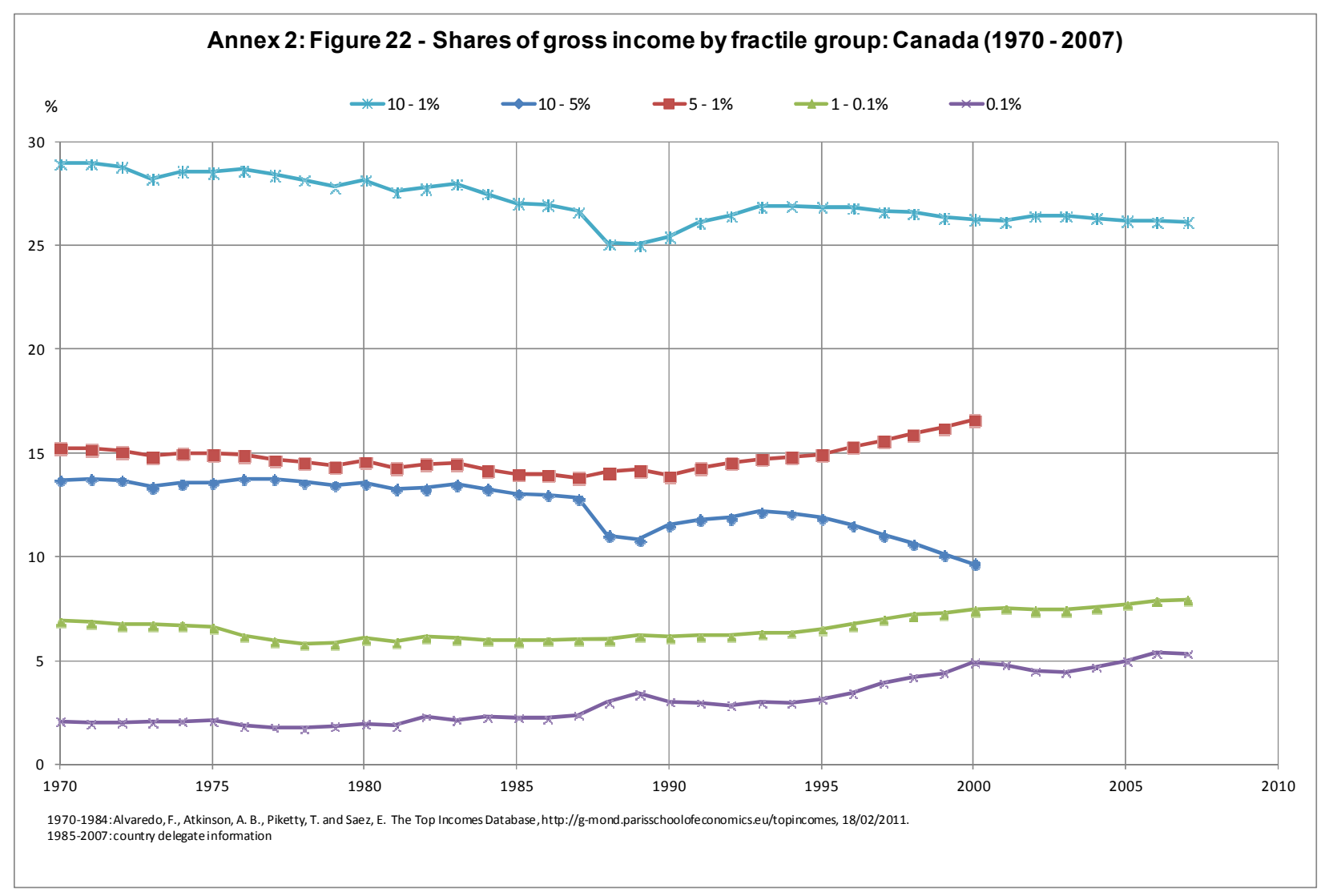



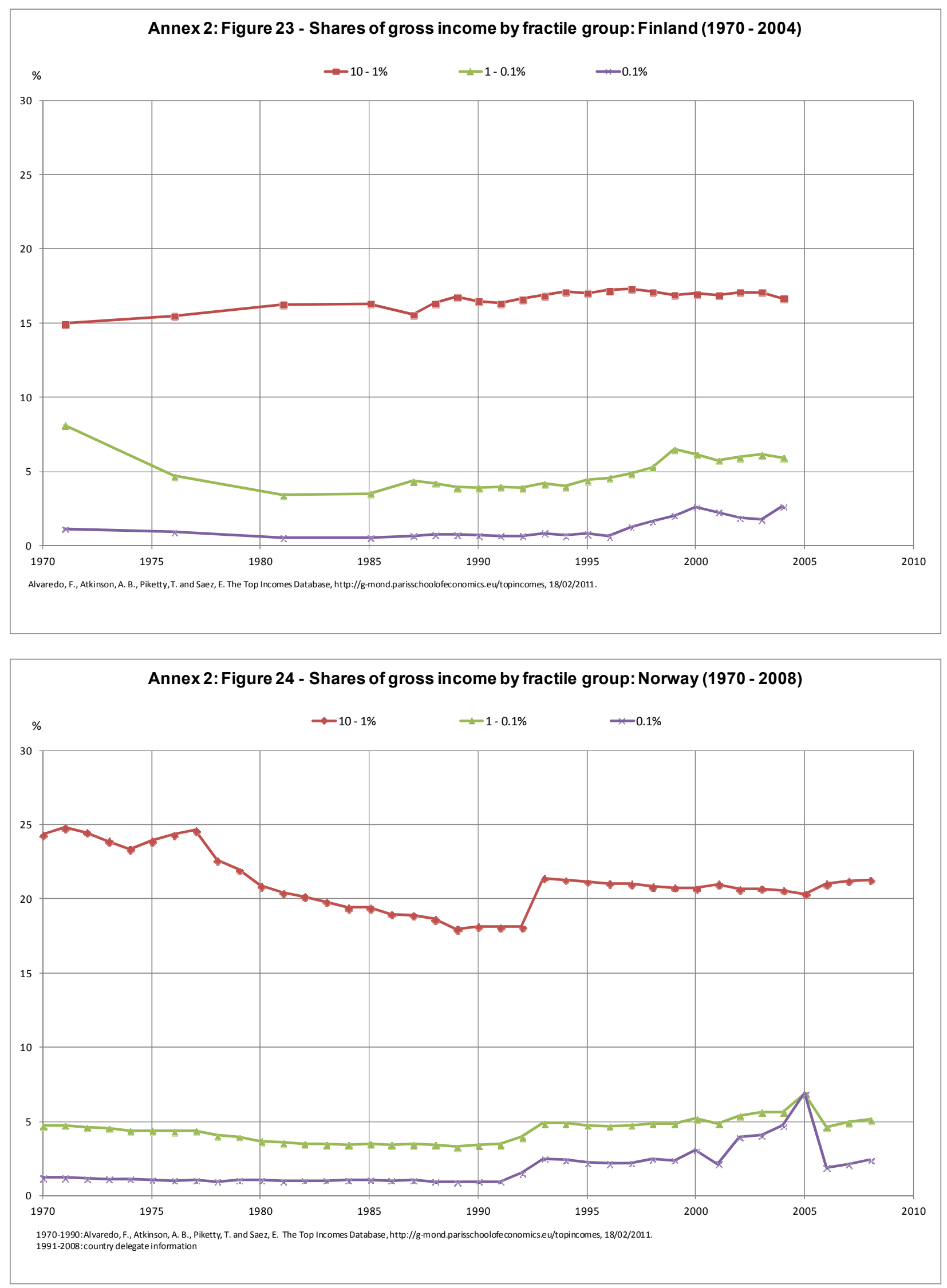


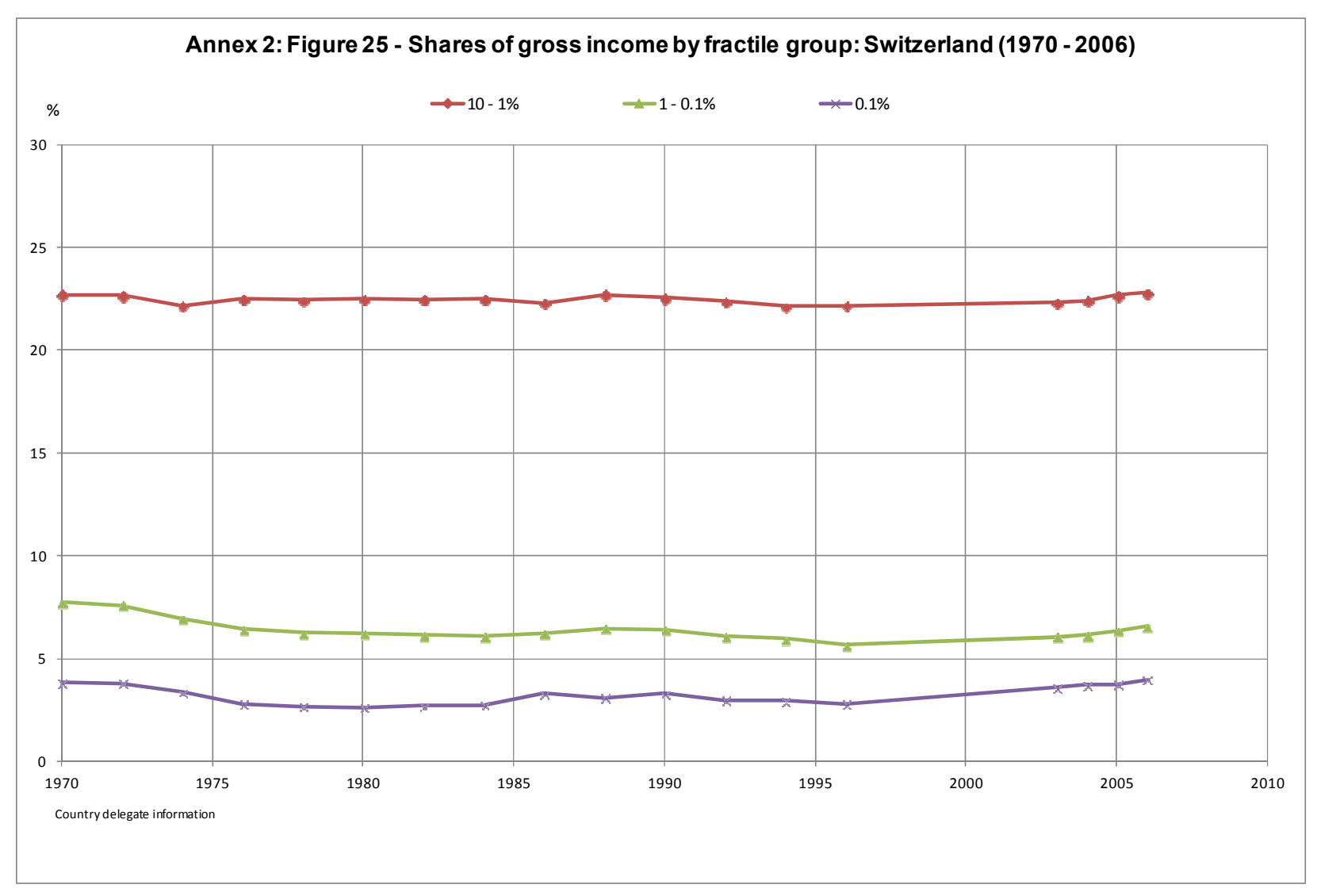




\section{OECD TAXATION WORKING PAPERS}

No. $1 \quad$ Tax reform trends in OECD countries

Bert Brys, Stephen Matthews and Jeffrey Owens

No. $2 \quad$ What is a competitive tax system?

Stephen Matthews

No. $3 \quad$ Making fundamental tax reform happen

Bert Brys

No. $4 \quad$ Trends in top incomes and income inequality and the implications for tax policy

Stephen Matthews

No. 5 The evaluation of the effectiveness of tax expenditures: a novel approach. An application to the regional tax incentives for business investments in Italy

Antonella Caiumi

No. 6 Corporate taxation and SMEs: the Italian experience

Marco Manzo

No. 7 Consumption taxation as an additional burden on labour income

Fidel Picos-Sánchez

No. $8 \quad$ Non-tax compulsory payments as an additional burden on labour income

Bert Brys

No. 9 Taxation and innovation

Pamela Palazzi

No. $10 \quad$ Wage income tax reforms and changes in tax burdens: 2000-2009

Bert Brys

No. 11 Shifting from social security contributions to consumption taxes: the impact on low-income earner work incentives

Alastair Thomas and Fidel Picos-Sánchez 


\section{THE OECD TAXATION WORKING PAPERS SERIES ON LINE}

The OECD Taxation Working Papers Series may be found at:

- The OECD Centre for Tax Policy and Administration website: www.oecd.org/ctp/workingpapers

- The OECD's online iLibrary: http://www.oecd-ilibrary.org/

- The Research Papers in Economics (RePEc) website: www.repec.org

For further information on the OECD Taxation Working Papers Series, please write to: ctp.contact@oecd.org. 